\title{
Comer e beber "até perder o juízo": o pecado da gula na literatura religiosa publicada em Portugal, século XVIII ${ }^{1}$
}

\author{
Piggin out "until you take leave of your senses": the sin of \\ gluttony in the religious literature published in Portugal, \\ 18th century \\ Mauro Dillmann* \\ http://orcid.org/0000-0002-8315-7788
}

\begin{abstract}
Resumo
Em Portugal do início do século XVIII foi profícua a impressão de livros religiosos que pedagogicamente visavam a instruir como os leitores deveriam evitar ações, pensamentos e sentimentos pecaminosos para adquirir condutas e virtudes entendidas como adequadas à moral e à fé católica. Entre as atitudes a serem controladas e modificadas estavam aquelas relacionadas ao consumo exagerado, prazeroso e curioso de comidas e bebidas. Neste artigo, a partir de um conjunto de obras religiosas impressas em Portugal, identificamos e analisamos os discursos sobre a gula, atentando aos significados religiosos e culturais do consumo alimentar demasiado, às instruções sobre os modos de evitar e remediar o "vício" e às percepções sobre os efeitos nocivos ao corpo e à alma. A partir de referenciais teórico-metodológicos da história cultural, e em diálogo com a historiografia voltada à alimentação e às ideias católicas da Idade Moderna, buscamos compreender os códigos culturais e simbólicos que conformavam os entendimentos da gula enquanto pecado. Em universo social fortemente cristão, concluímos que a escrita sobre a moderação no comer e no beber carregava juízos quanto aos comportamentos considerados legítimos para a garantia da salvação e reafirmava os propósitos da Igreja Católica no domínio moral dos corpos e das almas.
\end{abstract}

Palavras-chave: Igreja católica, Portugal, alimentação.

\begin{abstract}
In Portugal in the beginning of the $18^{\text {th }}$ century the printing of religous books that pedagogically aimed at teaching how the readers should avoid sinful
\end{abstract}

\footnotetext{
${ }^{1}$ Este texto resulta do projeto de pesquisa 0 pecado da gula: discursos religiosos em Portugal dos séculos XVII $e$ XVIII desenvolvido como Estágio Pós-doutoral do autor na Universidade Federal do Rio de Janeiro entre 2020 e 2021, sob supervisão do Prof. Dr. William de Souza Martins, a quem registro agradecimento

* Doutor em História pela Universidade do Vale do Rio dos Sinos (UNISINOS). Professor Adjunto do Departamento de História e do Programa de Pós-Graduação em História da Universidade Federal de Pelotas (UFPEL).E-mail: maurodillmann@hotmail.com
} 
actions, thought and feelings to acquire behaviors and qualities seen as adequate to moral and the Catholic faith was quite fruitful. Among the attitudes to be controlled and changed were the ones related to the exaggerated, pleasant and striking intake of foods and beverages. In this article, based on ranged of printed religious works in Portugal, we identified and analyzed the discourses about gluttony, focusing on the religious and cultual meanings of the excessive food consumption, to the instructions on how to avoid and cure the "addiction" and to the perceptions about the harmful effects to the body and soul. Based on theoretical-methodological standadrs of the cultural history, and in a dialogue with historiography associated with food and the Catholic ideas of Modern Age, we sought to understand the cultural and symbolic codes that were in compliance with the understandings of gluttony as a sin. In a strongly Christian social universe, we conclude that the writing on the moderation on eating and drinking had judgements concerning the behaviors considered as legitimate to assure salvation and reaffirmed the purposes of the Catholic Church in the moral domain of the bodies and souls.

Keywords: Catholic church, Portugal, feeding / food.

\section{Introdução}

A historiografia brasileira voltada à problematização do pensamento cristão-católico português do período moderno - seja no Reino ou no Ultramar - evidenciado na cultura escrita, com fontes impressas e manuscritas, tem apresentado diferentes enfoques e abordagens do universo religioso, como os processos de circulação de ideias cristãs, de atuações de sistemas jurídicos dos processos inquisitoriais e de divulgação de saberes e discursos doutrinários, normativos e morais. ${ }^{2}$ Este artigo se propõe a dialogar mais diretamente com os estudos sobre a dimensão cultural das compreensões católicas a respeito dos modos tidos como ideais de condução da vida como garantia de salvação

\footnotetext{
${ }^{2}$ Entre a vasta produção, destacamos as seguintes coletâneas: FEITLER, Bruno; SOUZA, Evergton Sales (org.). A Igreja no Brasil: normas e práticas durante a Vigência das Constituições Primeiras do Arcebispado da Bahia. São Paulo: Ed. Unifesp, 2011; FURTADO, Júnia; RESENDE, Maria Leônia (Orgs.). Travessias inquisitoriais das Minas Gerais aos cárceres do Santo Ofício: diálogos e trânsitos religiosos no império luso-brasileiro (sécs. XVI-XVIII). Belo Horizonte: Fino Traço, 2013; GANDELMAN, Luciana; GONÇALVES, Mrgareth; FARIA, Patricia Souza de (Orgs.). Religião e Linguagem nos mundos ibéricos: identidades, vínculos sociais e instituições. Seropédica: Ed. UFRRJ, 2015; HERMANN, Jacqueline; MARTINS, William de Souza (Orgs.). Poderes do Sagrado: Europa católica, América ibérica, África e Oriente portugueses (séculos XVI-XVIII). Rio de Janeiro: Multifoco, 2016; RODRIGUES, Aldair Carlos; et. al. (Orgs.). Edificar e transgredir: clero, religiosidade e Inquisição no espaço ibero-americano (séculos XVI-XIX). Jundiaí: Paco Editorial, 2016.
} 
da alma e de construção de uma sociedade disciplinada, segundo os códigos morais cristãos.

Em Portugal, na primeira metade do XVIII, foi profícua a impressão de livros religiosos, também chamados "de espiritualidade", ${ }^{3}$ que traziam, entre outros aspectos, instruções pedagógicas sobre maneiras de sentir e de manifestar determinados comportamentos, bem como aconselhamentos para o fácil alcance do que era entendido como caminho ideal para os cristãos alcançarem uma vida santificada. Dentre as instruções, destacavam-se aquelas que normatizavam os modos como os leitores deveriam evitar ações, pensamentos e sentimentos pecaminosos a fim de adquirirem condutas e virtudes entendidas como adequadas à fé católica. ${ }^{4} \mathrm{E}$, entre as atitudes a serem controladas e modificadas estavam aquelas relacionadas ao consumo exagerado, prazeroso e curioso de comidas e bebidas, já que desde o medievo, o discurso cristão estabeleceu a oposição entre alimento espiritual e alimento material, trazendo, para este último, uma conotação de tentação e pecado que atravessou o período moderno. ${ }^{5}$ Os vocábulos gulodice, intemperança e gula, já figuravam em inúmeros autores antigos e medievais europeus que enumeravam vícios/pecados capitais/mortais, conforme bem demonstrou o historiador Jean Delumeau. ${ }^{6}$

Na historiografia luso-brasileira alguma noção de gula geralmente perpassa rapidamente os estudos sobre alimentação e dietética, a depender, é claro, do contexto a que se referem. ${ }^{7}$ As peculiaridades sobre o comer e as considerações sobre o que configura, ou não, o excessivo, o perigoso, o pe-

\footnotetext{
${ }^{3}$ CARVALHO, José Adriano de Freitas (Org.). Bibliografia cronológica da literatura de espiritualidade em Portugal, 1501-1700. Porto: Instituto de Cultura Portuguesa, 1988.

${ }^{4}$ SÁNCHEZ, Carlos Alberto González. El espíritu de la imagen: arte y religión en el mundo hispánico de la Contrarreforma. Madrid: Cátedra, 2017, p. 24-25.

${ }^{5}$ BRAGA, Isabel Drumond. Sabores e segredos: receituários conventuais portugueses da Época Moderna. Coimbra: Imprensa da Universidade de Coimbra, 2015, p. 28.

${ }^{6}$ Segundo Delumeau, a noção de "pecados capitais" de Santo Agostinho passou a dominar a teologia desde então, ao conceituá-los como os vícios "incompatíveis com a graça (...), [que] fazem perder o direito ao céu adquirido pelo batismo e só podem ser remidos pela Igreja (...)” (DELUMEAU, Jean. o pecado e o medo: a culpabilização no ocidente (séculos XIII-XVIII). V. 1. Trad. Álvaro Lorencini. Bauru: Edusc, 2003, p. 368). No século XVIII, a lista dos sete pecados capitais seguiam esta ordem: soberba, avareza, luxúria, ira, gula, inveja, preguiça (SANTA CLARA, Pedro. Cathecismo, ou O Christão bem instruído. Lisboa: Officina Miguel Manescal da Costa, 1744, p. 372).

${ }^{7}$ Limitamo-nos a indicar aqui ALGRANTI, Leila Mezan. Refeições festivas e cotidianas em Portugal no século XVIII: as religiosas do Convento de Nossa Senhora dos Remédios (Braga). In: ANDRADE, Marta Mega; SEDREZ, Lise; MARTINS, William (Orgs.). Corpo: Sujeito e Objeto. Rio de Janeiro, Ponteio, 2012a, p. 203-220; ARAÚJO; ESTEVES (2015); ARAÚJO, Maria Marta L.; ESTEVES, Alexandra (Orgs.). Hábitos alimentares e práticas quotidianas nas instituições portuguesas. Braga: Diário do Minho, 2015; BRAGA, op. cit.
} 
caminoso, são demarcadas por fatores socioculturais ${ }^{8}$ e podem ser distintas numa mesma sociedade, de acordo com os grupos, os espaços e os horizontes de crença considerados. São diretamente relacionadas às dinâmicas próprias do seu tempo, que conformam entendimentos sobre a boa e a má alimentação, o permitido e o proibido, o aceito e o rejeitado e os modos ideais de comer e de beber. As historiadoras portuguesas Maria Marta Lobo de Araújo e Alexandra Esteves, ${ }^{9}$ enfatizaram que, em Portugal do século XVIII, instituições de diferentes naturezas (conventos, recolhimentos, hospitais, albergues) organizavam suas práticas alimentares mediadas pela conciliação entre as crenças religiosas, que pressupunham jejum, abstinência e penitência - com eliminação "de determinados produtos do regime alimentar" ou "suspensão de algumas refeições” - e a necessidade de sustentação saudável do corpo.

As problematizações historiográficas exclusivamente sobre os sentidos religiosos da gula nos séculos XVII e XVIII em Portugal ainda são lacunares ${ }^{10}$ e, devem-se, talvez em parte, pela ausência de documentação ou pela relativa pouca atenção que o tema mereceu dos autores religiosos do período. Embora fosse considerado um pecado capital, motivo de alerta e preocupação dos escritores católicos, a gula era tema a ocupar pouco espaço nas obras.

Assim, para compreender os entendimentos religiosos da gula, ${ }^{11}$ optou-se por acionar diversas obras publicadas em Portugal, não necessariamente de autoria portuguesa, mas aquelas que foram traduzidas e ganharam edição impressa no reino. Nossa análise está centrada basicamente em oito obras da primeira metade do século XVIII, escritas fundamentalmente por membros do clero regular pertencentes a diferentes ordens. A seguir, indicamos em ordem cronológica a edição publicada e consultada: Ideas sagradas, e consagradas em vários Sermoens Panegyricos (Lisboa, 1720), de Manoel de Lima, da Ordem de Santo

\footnotetext{
${ }^{8}$ Nesse sentido, ver os estudos antropológicos MACIEL, Maria Eunice; CASTRO, Helisa Canfield de. A comida boa para pensar: sobre práticas, gostos e sistemas alimentares a partir de um olhar socioantropológica, Demetria: Alimentação, nutrição \& saúde, 8 (supl. 1), p. 321-328, 2013; CONTRERAS; GRACIA, 2011; CONTRERAS, Jesús; GRACIA, Mabel. Alimentação, sociedade e cultura. Rio de Janeiro: Fiocruz, 2011.

${ }_{9}^{9}$ ARAÚJO; ESTEVES, op. cit., p. 05.

${ }^{10}$ Além dos já citados trabalhos, veja-se a tese de Fernando Ripe, especialmente o segmento sobre os regimes alimentares e a gula na infância (RIPE, Fernando. A constituição do sujeito infantil moderno na cultura impressa portuguesa do século XVIII. Tese (doutorado em Educação), PPGE, Universidade Federal de Pelotas, 2019, p. 125-134).

${ }^{11}$ Vale ressaltar o sentido etimológico da palavra: “do Latim Gula, significa literalmente 'garganta', o que originou a expressão 'engolir'. Tem sua origem na palavra Indo-Européia Gwel 'tragar'. O significado de gula toma a forma de 'voracidade'. Refere-se ao desejo insaciável de tragar sem medida, relacionado normalmente a comida, mas que está ligada a qualquer outro desejo insaciável". Disponível em https:// gnosisbrasil.com/artigos/origem-das-palavras/. Acessado em 23/09/2020.
} 
Agostinho; Exercícios admiráveis (Lisboa, 1728), de Boaventura Maciel Aranha; Director Espiritual, que ensina hum methodo fácil para viver santamente (Coimbra, 1731), do padre espanhol Gaugérico, da Congregação do Oratório, traduzida por um anônimo; Flagello do Pecado, composto de vários sermoens (Lisboa, Tomo I, 1734; Tomo II, 1736), de Paulo de Santa Theresa, do Seminário de Varatojo de Missionários Apostólicos; Cathecismmo ou O Christão bem instruído (Lisboa, 1744), de Pedro de Santa Clara, da Regular Observância de S. Francisco da Província dos Algarves; Avisos e Reflexões sobre o que deve obrar hum religioso (Lisboa, 1751), anônimo, de um religioso beneditino da Congregação de S. Mauro; Espelho monástico, e catholico (Coimbra, 1756), traduzida do latim por Joam Barba Rica, da Ordem Seráfica; ${ }^{12}$ Ramalhete Espiritual (Lisboa, 1764), de Jozé da Trindade, padre da Província dos Algarves. A escolha destas fontes pautou-se em dois critérios: a condição do acesso $^{13}$ e a possibilidade de identificação de capítulos com reflexões sobre o pecado da gula e/ou o sentido do gosto; essas obras formam um conjunto documental específico - dentre a enorme quantidade de publicações que circulava em Portugal no período -, mas pertinente para constituir uma amostra capaz de revelar os discursos religiosos sobre a gulodice e seus possíveis impactos para o corpo e a alma dos cristãos.

Ao consultarmos os referidos livros, nosso objetivo foi identificar os entendimentos da gula adotados pelos autores a partir de suas convenções morais e da compreensão doutrinária dos pecados, ${ }^{14}$ evidenciando também as instruções sobre os modos de evitar esse "vício" pela prevenção ou recuperação ("remédios") que acreditavam ser eficazes. Mais do que reconhecer simplesmente os meios indicados de tratar os desregrados modos e consumos exagerados à mesa, propomo-nos a analisar os entendimentos sobre os possíveis efeitos da gula para o corpo e para a alma.

\footnotetext{
${ }^{12}$ Escrita em latim pelo irmão do tradutor, Francisco Barba Rica. Como, à época, os tradutores desfrutavam de liberdade criativa, optou-se por manter a referência da autoria ao tradutor.

${ }^{13}$ Todas as obras citadas estão disponíveis online via google books, com referências completas apresentadas ao final desse texto.

${ }^{14}$ Além da obra de J. Delumeau, o pecado e o medo, vale referir a síntese realizada por J. Huizinga: “A gravidade do pecado precisa ser analisada segundo sete prismas: o de Deus, o do pecador, o da matéria, das circunstâncias, da intenção, da natureza do pecado e de suas consequências (...). 0 pecado é mais ou menos grave de acordo com os benefícios obtidos pelo pecador, com o seu conhecimento, com as virtudes anteriores, com o seu ofício, a sua consagração, a habilidade de resistir, a fé, a idade". Essa "anatomia do pecado" exacerbou a noção de castigo, de modo que "nenhum humano é capaz de entender completamente a enormidade do pecado durante a sua vida terrena" (HUIZINGA, Johan. 0 outono da Idade Média: estudo sobre as formas de vida e pensamento dos séculos XIV e XV na França e nos Países Baixos. Trad. Francis Janssen. São Paulo: Cosac Naify, 2010, p. 356).
} 
Nossa abordagem, com a história cultural como corrente interpretativa, considera a produção e difusão dos discursos religiosos sobre a gula em Portugal, seus entendimentos sobre as práticas do comer e do beber e o conhecimento dos seus efeitos sobre a saúde do corpo e a consciência de salvação da alma, que eram - ou teoricamente deveriam ser - partilhadas pelos grupos sociais católicos, leitores ou ouvintes. Trata-se de significados simbólicos compartilhados, mas não necessariamente aceitos com unanimidade, que permitiam a escrita, a tradução, a publicação e a leitura sobre a gula. Analisar, então, as recorrências textuais que conformavam as retóricas sobre a gula significa também pensar que códigos culturais compreensíveis eram esses e como e por que os autores e tradutores das obras religiosas - sujeitos do seu tempo - formulavam determinados juízos e entendimentos destinados ao mundo social cristão. ${ }^{15}$

Entre os séculos XVII e XVIII, nos discursos sobre a alimentação e seus consequentes excessos, foram conferidos quatro entendimentos que se conjugavam e, por vezes, se contrapunham ou se contradiziam: o médico (gula vinculada aos efeitos perniciosos à preservação da saúde ${ }^{16}$ ), o enciclopédico (gula como excesso e avidez no comer), o comportamental (gula ou glutonaria enquanto transgressão das normas de civilidade e etiqueta dos modos de $c o m e r^{17}$ ) e o religioso (gula enquanto intemperança, vício e pecado).$^{18} \mathrm{Na}$ Enciclopédia francesa do século XVIII, o verbete gourmandise apresentava dife-

\footnotetext{
${ }^{15}$ Vale reforçar que estamos interessados nos discursos, e não nas práticas de leitura e nas relações estabelecidas com o universo leitor, que implicaria pensar nas apropriações (plurais), nas formas de transmissão e na recepção (CHARTIER, Roger. À beira da falésia. A História entre certezas e inquietudes. Porto Alegre: Ed. UFRGS, 2002).

${ }^{16} \mathrm{Cf}$. ABREU, Jean Luiz N. Nos domínios do corpo: o saber médico luso-brasileiro no século XVIII. Rio de Janeiro: Fiocruz, 2011, p. 161.

${ }^{17}$ Veja-se a obra Corte na Aldeia [1 ${ }^{a}$ ed. de 1619], do português Francisco Rodrigues Lobo, que alertava sobre regras de comportamento à mesa, dentre as quais: "O comer há de ser com sofreguidão, sem mostra de gula, nem demasiado apetite; e também não mostrar uma frieza cheia de fastio, que é desagradecer a comida e a vontade do que lha oferece" (LOBO, Francisco Rodrigues. Corte na Aldeia. Introdução de Maria Ema T. Ferreira. Lisboa: Editorial Verbo, 2005 [1619], p. 327). Analisando mudanças nos códigos de comportamento, especialmente na França dos séculos XVI e XVII, Norbert Elias trouxe inúmeros exemplos de hábitos e modos à mesa desde o Renascimento. Já no século XIII, às "classes altas" o "comer voraz" era indecoroso; as mudanças nos comportamentos atingiam a busca pela aprendizagem dos refinamentos da polidez vivenciados pela sociedade de corte do século XVII e a Igreja relevava-se "um dos mais importantes órgãos da difusão de estilos de comportamento pelos estratos mais baixos" (ELIAS, Norbert. o processo civilizador. Vol. 1: uma história dos costumes. Trad. Ruy Jungmann. Revisão e apresentação: Renato Janine Ribeiro. $2^{\mathrm{a}}$ ed. Rio de Janeiro: Zahar, 2011, p. 91, 106-107).

${ }^{18}$ Duas relevantes pesquisas, em abordagem ampla sobre a gula no Antigo Regime europeu são QUELLIER, Florent. Gula: história de um pecado capital. Trad. Gian Bruno Grosso. São Paulo: Senac São Paulo, 2011 e VON HOFFMANN, Viktoria. From Gluttony to Enlightenment: the world of taste in Early Modern Europe. Urbana: University of Illinois Press, 2016.
} 
rentes entendimentos, todavia começava referindo o "amor à boa mesa", uma decorrência da ostentação, com exemplos dos requintes e prazeres gastronômicos da Antiguidade. Mas em 1771, um dicionário publicado pelos jesuítas, Dictionnaire de Trévoux, contrapunha essa prática, afirmando a "vergonhosa" gourmandise como "o vício de quem come com avidez e em excesso" e "um dos sete pecados capitais". ${ }^{19}$ Portanto, é perceptível que, no período, já circulavam na França - e com impactos em Portugal - compreensões contraditórias e supostamente ambíguas a respeito da gula, a depender dos interesses de quem enunciava. Em todo caso, associava-se a gula tanto ao ambiente cotidiano da cozinha, da preparação e do consumo de alimentos, quanto aos espaços de sociabilidade que requisitavam confraternizações "regadas" a bebidas alcoólicas. O comer e o beber poderiam demonstrar o requinte do gosto e da apreciação à boa mesa, ou, representar uma ameaça à conduta santa e à esperança salvífica. No entanto, para os religiosos a compreensão e definição da gula, como veremos na sequência, era constituída quase por um discurso padrão, num alinhamento normativo que não somente restringia o consumo de comidas e bebidas, como incitava certo temor dos perigos que o pecado poderia acarretar aos fiéis cristãos.

\section{A gula e seus significados religiosos}

Como vício, tentação, deleite ou perversão, inúmeros foram os adjetivos dados à gula por religiosos de diversas ordens, em discursos moralizantes presentes nas obras publicadas em Portugal durante o século XVIII. As considerações apontavam para a gula enquanto um pecado capital, resultado do permitir-se à tentação que, por sua vez, dificultava a sujeição do corpo ao espírito. ${ }^{20} \mathrm{Com}$ pequenas variações, claramente inspiradas em bispos e doutores antigos e medievais da Igreja - entre outros, São Jerônimo, São Gregório, Santo Ambrósio e Santo Agostinho - os entendimentos dos religiosos apontavam características extremamente negativas para esse considerado defeito humano associado à vontade e ao ato de comer e beber.

\footnotetext{
${ }^{19}$ Apud FLANDRIN, J. L. A distinção pelo gosto. In: ARIES, P.; CHARTIER, R. História da vida privada: da Renascença ao Século das Luzes. São Paulo: Companhia das Letras, 2009, p. 288.

${ }^{20} \mathrm{Ao} \mathrm{clero}$ a responsabilidade diante da tentação alimentar tinha um peso maior, pois mais compromissado com a necessidade de enfraquecer as vontades do corpo. O beneditino anônimo, autor de Avisos e Reflexões, dizia ser lastimoso e indigno "que um religioso, fazendo profissão de uma vida penitente e mortificada, e devendo tratar o seu corpo como um inimigo, a quem importa enfraquecer, ame os manjares deliciosos, busque a delicadeza e o gosto no sustento" (ANÔNIMO. Avisos e Reflexões sobre o que deve obrar hum religioso, para satisfazer ao seu Estado. Por hum religioso Benedictino da Congregação de S. Mauro. Tomo I. $4^{a}$ edição. Lisboa: Officina de Joseph da Costa Coimbra, 1751, p. 425).
} 
Se resumidamente a gula podia ser definida apenas como o comer e beber "até perder o juízo", ${ }^{21}$ por outro, ganhava definições mais amplas:

comer mais por satisfazer o apetite, do que por sustentar a natureza; antecipar o tempo da comida, ou pospollo (sic) sem causa legítima: buscar com demasiada curiosidade os manjares delicados, e com mais despeza, do que convém; beber, e comer mais do que se requer para sustentar a vida, e a saúde. ${ }^{22}$

Então, comer por mero apetite e satisfação pessoal, por antecipação de refeições ou simplesmente por curiosidade, sem uma causa que fosse considerada legítima, como alimentar e saciar a fome ou cuidar da saúde, ou o que fosse necessário para viver, conformavam a prática da gula. ${ }^{23}$ De modo similar, Rafael Bluteau, ${ }^{24}$ trazia no seu Vocabulário, a gula enquanto o comer e beber "fora do tempo" e ainda o vício dos "comeres proibidos". Em outra publicação, Primicias Evangelicas (1685), ${ }^{25} \mathrm{o}$ autor era bem mais enfático ao destacar a gula como a "voracidade da intemperança". Desse modo, com outros juízos, o teatino fazia crer que haveria determinadas comidas que, para alguns, talvez fossem proibidas, embora não as especificasse. ${ }^{26}$ Portanto, a gula não estava vinculada apenas ao sentido de comer muito ou exageradamente, mas também ao prazer do contentamento e do interesse alimentar, bem como ao modo voraz de comer, incluindo o consumo de bebidas.

Seguindo essa mesma compreensão, mas com algumas peculiaridades, outro religioso, Pedro de Santa Clara, além de apontar a gula como a prática do comer "com demasia", ingerindo "mais do que é lícito", abordava outros

\footnotetext{
${ }^{21}$ SANTA THERESA, Paulo de. Flagello do peccado. Lisboa: Officina Antonio Pedrozo Galram, Tomo I, 1734; Tomo II, 1736, p. 111.

${ }^{22}$ GAUGÉRICO. Director Espritual, que ensina hum methodo fácil para viver santamente. Coimbra: Officina Antônio Simões Ferreyra, 1731, p. 296.

${ }^{23} \mathrm{O}$ padre Luís de Granada, em Guia de Pecadores, obra do século XVI com grande repercussão durante todo o período moderno, alertava para a transitoriedade da satisfação causada pelo prazer do comer e do beber, comparando-a com o bom sonho que, quando acaba, deixa triste a consciência (GRANADA, Luís de. Guia de pecadores...Tomo II. Barcelona: Juan Sellent, 1792 [1570], p. 325). E Jozé da Trindade, questionava: "Que há de sonhar o glutão, senão com comeres, e manjares, que apetece a sua gula?" (TRINDADE, Jozé Fr. Ramalhete Espiritual composto com as flores dos doze sermoens Doutrinaveis, que no Reyno de Portugal pregou o insigne Orador Missionario Apostolico, o Veneravel padre Fr. Antonio das Chagas. Lisboa: Officina de Francisco Borges de Sousa, 1764, p. 348).

${ }^{24}$ BLUTEAU, Raphael. Vocabulario portuguez \& latino. Vol. IV. Coimbra: Collegio das Artes da Companhia de Jesus, 1728, p. 159.

${ }^{25}$ BLUTEAU, Rafael. Primicias Evangelicas, ou sermoens, e panegyricos. Lisboa: Officina Miguel Deslandes, 1685.

${ }^{26} \mathrm{O}$ mesmo foi ressaltado por Boaventura Aranha ao apontar para as "coisas" más para os cristãos, como ver o provocativo, ouvir cantares lascivos ou comer "cousas vedadas" (ARANHA, Boaventura Maciel. Exercicios admiráveis para os dias do recolhimento interior. $2^{\mathrm{a}}$ ed. Lisboa: Officina Antonio Pedrozo Galram, 1728, p. 185).
} 
modos de se alimentar e beber que conformavam os entendimentos da gula, tais como: comer "fora de tempo", antes das horas determinadas; o comer com deleite "manjares extraordinários"; comer "com voracidade", exagerando na forma do consumo; comer "com curiosidade", procurando "manjares esquisitamente temperados". ${ }^{27}$ Assim, os discursos religiosos tenderam a formular, em suas narrativas, ligações entre as concepções doutrinárias do pecado e outros aspectos, como as maneiras de se portar à mesa e as especificidades culinárias disponíveis. Esses vínculos convidavam o leitor a elaborar um juízo que os próprios autores traziam a respeito da relação entre o corpo, a comida e os sabores. O pecado da gula, na crítica religiosa, resultava de uma identificação da rendição do corpo ao prazer do gosto e do contentamento com comidas "proibidas" e com sabores diversos, "esquisitos" ou muito temperados, bem peculiares, aliás, da cozinha portuguesa da época.

Mesmo que indiquem a restrição de determinados alimentos, raramente os autores apontavam para a tipologia alimentar a que se referiam, de tal forma a que pudéssemos, hoje, associar diretamente determinados alimentos à gula, ${ }^{28}$ e quando o faziam era como recurso metafórico para referir as benesses e "delícias" do céu. Por exemplo, mencionava-se "o amor Divino é como um mel, ou um açúcar misterioso, que faz muito doce”. ${ }^{29}$ No final do século XVII, Manoel da Conceição, em forma de aviso, alertava aos pecadores que viviam "pela regra de seus desejos": "passaram alegremente a vida inventando cada dia os homens e mulheres (...) novos pratos, novas iguarias, novas traças de conservas, novas invenções de doces para o gosto [e] para o apetite, para o regalo, (...) esquisitas invenções" ${ }^{30}$ A referência culinária era genérica, a indicar, no máximo um ou dois ingredientes (mel, açúcar) e seu resultante (doce, conserva) e geralmente a tônica proibitiva perpassava a noção de alimentos saborosos, como polpas de frutas doces. ${ }^{31}$ Desse modo, as principais proibições acerca dos regimes alimentares dos católicos estavam vinculadas ao açúcar

\footnotetext{
${ }^{27}$ SANTA CLARA, op. cit., p. 354.

${ }^{28}$ Poucas vezes os livros espirituais eram mais incisivos e diretos em relação aos alimentos proibidos ou consumidos em exagero. O frade Paulo de Santa Theresa $(1736$, p. 23) ressaltava a indiferença do guloso em comer "de tudo", incluindo "frutos e carnes". A ausência de nomeação explícita dos alimentos poderia ser indicativo de que o problema não estava em consumir, ou não, determinados alimentos ou em estabelecer uma hierarquia alimentar, mas sim em indicar, em geral, o consumo moderado.

${ }^{29}$ ANÔNIMO, op. cit., p. 177.

${ }^{30} \mathrm{CONCEIÇÃO}$, Manoel da. Escola de Penitência, e flagelo de viciosos costumes. Lisboa: Officina Miguel Deslandes, 1687, p. 105-106.

${ }^{31} \mathrm{Na}$ Europa moderna e católica, esse movimento de aproximação entre frutas e paladar e jardim como local de delícias esteve presente, de modo que a noção de paraíso na terra esteve associada à concepção de um jardim tanto na literatura quanto na pintura (VON HOFFMANN, op. cit.).
} 
e a toda a doçaria dele resultante, como fez entender também o historiador Florent Quellier, ${ }^{32}$ embora, como mostrou Isabel Braga ${ }^{33}$ a produção doceira conventual - para consumo, para presentear confessores ou familiares, para ofertar a viandantes ou mesmo para comercializar - tenha ganhado destaque no início do século XVIII.

Se os religiosos faziam poucas referências aos alimentos proibidos ou menos aconselháveis aos homens e às mulheres, para as crianças, a atenção era diferente. $O$ pesquisador Fernando Ripe, analisando obras pedagógicas, médicas e religiosas constatou que no século XVIII português as instruções para o regime alimentar dos infantis era específico e passava por rigorosas restrições, como a desaprovação de bebidas alcoólicas, excesso de carnes, alimentos muito salgados ou picantes e doçuras. ${ }^{34}$ A gula infantil passava pelo controle dos pais e, entre os grupos mais pobres da hierarquia social predominavam alimentos como o leite materno, papas e caldos, principalmente os preparados com miolo de pão e açúcar. ${ }^{35}$

Diversos estudos já indicaram as particularidades da cozinha portuguesa entre o final do século XVII e o início do XVIII - momento em que circularam tratados culinários - que estavam pautadas na diversidade alimentar, mesmo entre os grupos sociais dos estratos mais baixos. Na dieta do período, os alimentos mais empregados, com amplo alcance social estavam peixes secos, sardinhas, bacalhaus, pães, legumes e frutas. Grupos privilegiados e conventuais consumiam, além da peixaria, do pão e da sopa, carnes variadas (gado, cordeiro, galinha, peru, pato, coelho, porcos) e seus derivados, como leites, natas, queijos, ovos, linguiças, chouriços. ${ }^{36} \mathrm{Em} \mathrm{A}$ arte da cozinha [1 $1^{a}$ edição de 1680], Domingos Rodrigues ampliava a lista de alimentos a serem consumidos, apresentando receitas de sopas, carnes, peixes, mariscos, ovos, galinhas, javalis, perdizes e pombos, e a indicação do uso nada econômico de diversas especiarias como canela, cravo, noz-moscada, açúcar e açafrão. ${ }^{37}$ Embora a ingestão de doces fosse uma prática potencial para o pecado da gula,

\footnotetext{
${ }^{32}$ QUELLIER, op. cit., p. 94.

${ }^{33}$ BRAGA, op. cit., p. 37-38.

${ }^{34}$ RIPE, op. cit., p. 99-100.

${ }^{35}$ Ibidem, p. 130.

${ }^{36}$ Veja-se mais em CASTELO-BRANCO, Fernando. Lisboa Seiscentista. Lisboa: Livros Horizonte, 1990, 107-108; FERREIRA, F. A. Gonçalves. História da saúde e dos serviços de saúde em Portugal. Lisboa: Fundação Gulbenkian, 1990; ALGRANTI, op. cit., p. 205-210.

${ }^{37}$ MONTELEONE, Joana. Sobre reis, livros e cozinheiros: notas para uma pequena história dos tratados de cozinha em português. In: ALGRANTI, Leila Mezan; MEGIANI, Ana Paula (orgs). 0 Império por Escrito: formas de transmissão da cultura letrada no mundo ibérico, séculos XVI-XIX. São Paulo: Alameda, 2009, p. 431.
} 
o consumo do açúcar ganhou relevância, como já destacamos, e inúmeras instituições religiosas, masculinas e femininas, destacavam-se com a produção intensa de uma doçaria especializada, como biscoitos, bolos, pastéis, tortas, doces variados, a partir de ingredientes como ovos, leite, amêndoas e frutas (maçãs, marmelos, peras, etc.). Exemplo é o livro de receita do Convento de Santa Clara de Évora, de 1729, cujos títulos compostos atribuídos às receitas aludiam "ao corpo feminino e ao universo religioso", como por exemplo, "barriguinhas de freiras, queijinho do céu, bolo do paraíso e manjar celeste", ${ }^{38}$ levando sugestivamente a crer no potencial de tentação dos seus sabores. ${ }^{39}$

A atenção às distinções sociais, em termos de condição e acesso aos diferentes alimentos, aos executores dos pratos (cozinheiros) e às "superficialidades" não escapou do padre Manoel da Conceição, na obra Escola de penitencia (1687), que faz um contraponto entre os "ricos", diretamente identificados como gulosos, e os "pobres". Assim, comparava a mesa farta de demasias dos "glutões", com a faminta dos "pobres":40

O glutão, fazendo capricho da culpa, só se lembra de comer, \& beber muito à larga; procurando com insaciável cuidado os melhores pescados, as melhores carnes, os melhores vinhos, as melhores frutas, os mais estremados cozinheiros, sendo na sua mesa tudo demasias, na sua casa tudo sobejos, tudo superficialidades; \& na do pobre, tudo fome, tudo miséria, tudo pobreza, sem ainda de tantas demasias lhe chegara uma pequena parte. ${ }^{41}$

\footnotetext{
${ }^{38}$ BRAGA, op. cit., p. 16.

${ }^{39}$ A respeito dos alimentos e das receitas que se preparavam em conventos e monastérios durante a Idade Moderna, algumas das quais ficavam em segredo, eram transmitidas apenas pela oralidade ou construídas coletivamente, veja-se CASTRO, Inês de Ornellas e; BRAGA, Isabel Drumond. Una Escritura Femenina Diferente: los Manuscritos Culinarios Conventuales Portugueses de la Edad Moderna. In: LETURIO, Nieves Baranda; PINA, María Carmen Marín (eds.). Letras en la Celda: cultura Escrita de los Conventos Femeninos de la España Moderna. Madrid: Iberoamericana; Vervuert, 2014, p. 439-455.

${ }^{40}$ A referência aos "pobres" como aqueles que não teriam a possibilidade de desfrutar dos prazeres perniciosos da gula já aparecia em Luís de Granada (1792 [1570]). Também Antônio Vieira, diante da máxima "Comamos e bebamos, porque amanhã havemos de morrer", argumentava que se "todos havemos de morrer (...) o maior favor que Deus pode conceder a um mortal (...) é que morra e chegue lá mais tarde”. $\mathrm{E}$, quase que justificando a fome por uma inversão simbólica do acesso às condições alimentares ideais, dizia que a prorrogação da vida (o "chegar lá mais tarde") é "privilégio dos pobres, a quem a Providência Divina quanto nega de abundância e regalo, tanto acrescenta de vida” (VIEIRA, Antonio. Sermão da quarta dominga depois da Páscoa. Com comemoração do Santíssimo Sacramento. Pregado em S. Luiz do Maranhão, Revista Latinoamericana de Psicopatologia Fundamental, v. 9, n. 3, São Paulo, p. 538-564, Jul./Set. 2006 [1677], p. 553). Entre os médicos, no século XVIII, atribuía-se aos pobres a alimentação mais simples: “os pobres, que ordinariamente vivem de seu trabalho, comendo alimentos de pouca substância, é muito necessário que bebam vinho" (HENRIQUES, Francisco da Fonseca. Ancora medicinal para conservar a vida com saúde. Lisboa: Officina Miguel Rodrigues, 1731 [1721], p. 428).
}

${ }^{41}$ CONCEIÇÃO, op. cit., p. 118-119. 
Independente das condições alimentares, havia variações quanto à culpa e ao peso dado ao pecado da gula, podendo ser de dificuldades na busca pela vida virtuosa ou de geração de condição inescapável de condenação da alma, especialmente em relação à embriaguez. Entre as várias maneiras de se referir à gula, os autores não eram unânimes em estabelecer as características alimentares que conferiam sentido à gula diretamente enquanto um pecado capital. De todo modo, uma vez glutão, o fiel estaria facilmente suscetível ao vício que poderia ser considerado "capital" quando as faces da gula se tornassem causas - "raízes e cabeças" - de outros pecados. ${ }^{42}$ Mesmo assim, de modo geral, a gula já estava na origem do pecado original (a maçã de Adão e Eva), ${ }^{43}$ motivo pelo qual poderia ser encarado como a "causa de todos os pecados", ${ }^{44}$ sendo inclusive capaz de conduzir ao descumprimento de "todos os dez mandamentos", segundo o padre Manoel de Lima. ${ }^{45}$ Para esse religioso, autor da obra Ideas sagradas, e consagradas, "se o povo está entregue à intemperança, saibam que daquela gula a formal consequência, é quebrarem-se todos os preceitos da Lei Divina", ${ }^{46}$ numa referência à inobservância dos mandamentos advindos do abuso do sentido do gosto. E embora não citada no Decálogo, a gula em caso de embriaguez, movia ao menos à transgressão de três proibições, como apontou Florente Quellier: ${ }^{47}$ guardar os domingos e festas, não pecar contra a castidade e não desejar a mulher do próximo.

O padre Jozé da Trindade (amparado nos escritos de Antônio das Chagas), na obra Ramalhete Espiritual (1764) e o padre Pedro de Santa Clara na obra Cathecismo, ou O Christao bem instruído (1744), apontavam que não seria a gula em si, mas a "demasia da gula" o pecado por excelência. Para Pedro de Santa Clara, a gula era um pecado venial por não repugnar à caridade, mas que poderia se tornar capital na medida em que comprometesse outras virtudes e

\footnotetext{
${ }^{42}$ SANTA CLARA, op. cit., p. 32.

${ }^{43}$ Os autores sugerem que a gula teria sido a primeira tentação humana na Terra. É Manoel Bernardes, em Luz e Calor, quem faz tal referência: entre as tentações que acometeram o "Senhor no deserto, a primeira foi a gula” (BERNARDES, Manoel. Luz, e Calor. Lisboa: Officina Miguel Deslandes, 1696, p. 281).

${ }^{44}$ BARBA RICA, Joam. Espelho monástico, e catholico. Coimbra: Real Collegio das Artes da Companhia de Jesus, 1756 , p. 10. Vale aqui um contraponto à ideia do inglês Robert Burton, para quem a gula era causa de "todos os males", a matar "mais que a espada", conforme escrevia em A Anatomia da Melancolia, volumosa obra de 1621 (BURTON, Robert. A Anatomia da Melancolia. V. II. Trad. Guilherme Gontijo Flores. Curitiba: Ed. UFPR, 2012 [1621], p. 23).

${ }^{45}$ LIMA, Manoel. Ideas sagradas, e consagradas em vários Sermoens Panegyricos. Tomo I. Lisboa: Officina de Mathias Pereyra da Sylva \& Joam Antunes Pedrozo, 1720, p. 429.

${ }^{46} \mathrm{Ibidem}$.

${ }^{47}$ QUELLIER, op. cit., p. 98.
} 
ofendesse a saúde pela voracidade da ingestão alimentar. ${ }^{48}$ Nota-se que para Santa Clara o maior erro estava no modo voraz de comer e não no consumo exagerado em si. De modo similar, o dominicano português João Franco, em Mestre da Virtude,${ }^{49}$ dizia que "no vício da gula não é proibido desejar os manjares, nem ainda o comê-los" 50 . Assim, a oscilação na mensuração da gravidade do pecado da gula estava relacionado ao vínculo que poderia ganhar com outras formas de pecar devido à perda da saúde ou da razão e do juízo, de modo a desenvolver o corpo enfermo ou o corpo lascivo e luxurioso. Não se pode menosprezar também que esse abrandamento em relação à gravidade da gula, em alguns autores, representava certamente o contato com outras perspectivas sobre a alimentação, como aquela da racionalidade leiga iluminista que associava positivamente a gula ao apetite e interesse gastronômico. ${ }^{51}$

Outra obra a dedicar inúmeras páginas a explicar, a partir de trechos bíblicos, os motivos para a recriminação da gula foi Espelho Monastico e catholico (1756), traduzido do latim para o português pelo Fr. Joam Barba Rica a partir do Tratado do modo de bem viver, escrito por São Bernardo. Para este autor a gula adquiria peso considerável enquanto pecado a limitar a perfeição e a salvação: "Ninguém pode alcançar a perfeição nas virtudes se primeiro não triunfar da gula e dos seus apetites", ${ }^{52}$ incluindo aqui a bebida, pois "o excesso

\footnotetext{
${ }^{48}$ SANTA CLARA, op. cit., p. 356.

${ }^{49}$ FRANCO, João. Mestre da Virtude, segunda parte do Mestre da Vida, que persuade a todas as criaturas de qualquer estado que sejam, o que é necessário para se salvarem, e o que hão de fazer para serem santos. Lisboa: Oficina dos herd. de Antonio Pedrozo Galvão, 1745, p. 232.

${ }^{50}$ Outras flexibilidades já eram divulgadas entre os cristãos de outras regiões da Europa, mas não nas obras aqui analisadas que circularam em Portugal. 0 padre francês Betaut Bertin, na obra Catéchisme des confesseurs (1634), bem mais permissivo, afirmava que "a busca do prazer da boa comida como único fim não é um pecado" (Apud QUELLIER, op. cit., p. 94).

${ }^{51}$ Mudanças estas que estariam refletidas, no início do século XIX, na principal obra do político e cozinheiro francês Jean Anthelme Brillat-Savarin (1755-1826), A fisiologia do gosto (1825), na qual definia este sentido como a apreciação ao que é sápido e dizia que os "últimos séculos" estenderam o gosto com a descoberta do açúcar (e seus usos), das bebidas alcóolicas, dos glacês, da baunilha, do chá e do café (BRILLAT-SAVARIN. A fisiologia do gosto. Trad. Paulo Neves. São Paulo Companhia das Letras, 1995 [1825], p. 33, 38).

${ }^{52}$ BARBA RICA, op. cit., p. 03. A perfeição cristã, segundo o padre jesuíta espanhol Afonso Rodrigues (15381616), na obra Exercícios de perfeição e virtudes cristãs (1609), exigia o alcance do ideal de pobreza das coisas necessárias, rompendo, entre outras coisas, com a acomodação no comer e enfrentando com alegria os efeitos da fome, sede, frio, cansaço e desnudez (RODRIGUES, Afonso. Exercícios de perfeição e virtudes cristãs. Tomo III. São Paulo: Cultor de Livros, 2017 [1609], p. 172-173). Ainda que a longo prazo tais concepções circulassem, em meados do século XVIII, em Portugal, o padre João Franco registrava o que considerava algumas transgressões dos conventuais: condenava tanto o comer demasiadamente ou às escondidas, como os comportamentos alimentares, que incluíam o "uso de babadores no peito ou do guardanapo sobre o ombro, ao hábito de despedaçar a carne com as mãos, de morder o pão com os dentes, de comer depressa, de meter três dedos no prato e de falar com a boca cheia" (FLECK, Eliane Cristina Deckmann; DILLMANN, Mauro. "E se o frade quiser ser perfeitinho": instruções para uma conduta exemplar do clero regular português no século XVIII. Revista Maracanan, n. 20, p. 30-50, jan. 2019, p. 47).
} 
de beber, quando faz mal ao discurso, é um pecado mortal gravíssimo". ${ }^{33} \mathrm{De}$ modo similar, apontava Boaventura Aranha: quem "não vencer primeiro a gula, em vão trabalha para vencer outros vícios". ${ }^{54}$ Cumpria-se, assim, o estabelecimento de uma hierarquia entre os pecados, embora o tom dramático predominasse nos discursos religiosos quando se referiam às necessidades de mudanças nos comportamentos dos fiéis.

Para outros, como Paulo de Santa Theresa, ${ }^{55}$ o guloso comparar-se-ia a um animal; ${ }^{56}$ nesse caso, o sujeito dado à gula seria semelhante a um urso feroz e faminto, mas que certamente sofreria com a atuação de um demônio, que capitaneava a gula, chamado Behemet, cuja "fortaleza" estaria no ventre humano. ${ }^{57}$ Por se tratar de sermões, os escritos desse último religioso receberam o tom apelativo típico da oralidade sermonística, especialmente quando refere o impacto demoníaco sobre a tentação da gula. A esse respeito, o autor, em estratégia disciplinadora dos fiéis por meio do medo, ilustra um diálogo com o demônio para justificar a condenação do guloso: "Eu sou o demônio, este desgraçado me vendeu a alma por mais comer e beber: já recebeu o preço: agora ordena o Altíssimo que em corpo e alma o leve para o Inferno; e acabando de proferir estas palavras desapareceu o demônio com o homem para aqueles cárceres eternos". ${ }^{58}$ Havia também contradições na expressão dos sentidos da gula, às vezes, em um mesmo autor, como o próprio Paulo Santa Theresa. No tomo 2 dos seus sermões, lembrava os leitores/ouvintes sobre o perigo de vender a alma ao demônio em troca de breves doçuras e deleites. ${ }^{59}$ Em outro momento, no Tomo 3 de seus sermões, parece atenuar o caráter condenatório da gula. Para ele, se foi "só" a gula, o excesso de comida e bebida, poderia bastar uma mortificação, o jejum: "se só a gula pecou, se o

\footnotetext{
${ }^{53}$ BARBA RICA, op. cit., p. 26.

${ }^{54}$ ARANHA, op. cit., p. 188.

${ }^{55}$ SANTA THERESA, op. cit., p. 57.

${ }^{56}$ A relação dos pecados com o símbolo animal era antigo. E. Malê teria localizado um manuscrito de 1390 na Biblioteca nacional francesa que estabelecia relações entre os pecados, níveis sociais e representações animais, dentre os quais a gulodice era comparável a "um rapaz", a "lobo" e um "gavião". Apud DELUMEAU, op. cit., p. 452. No século XVII, o conhecido padre Manoel Bernardes comparava o guloso, que "tem o ventre na goela" à ave Onacrotalo (pelicano), que teria "um ventre donde mete tudo, sem diferença do limpo ao imundo" (BERNARDES, Manoel. Nova Floresta. Tomo V. Lisboa: Officina Joseph Antonio da Sylva, 1728, p. 175).

${ }^{57}$ SANTA THERESA, op. cit., p. 330.

${ }^{58}$ Ibidem, p. 231.

${ }^{59}$ Ibidem.
} 
pecado só foi excesso, e demasia no comer, e beber, mortifique-se, e jejue a gula, e basta...". ${ }^{60}$

O que predominava nos discursos mobilizados pelos autores religiosos era a acentuação da urgência em combater a gula diante da necessidade em fazer aprimorar a vida santificada e virtuosa dos fiéis nos termos da moral cristã-católica, mas havia gradações cujas oscilações dependiam certamente do momento, do público e do objetivo no contexto amplo da obra. Ou a gula tomava a dianteira de todos os pecados, com merecimento de condenação infernal, ou ganhava um tom mais ameno, com necessidade de mortificação ${ }^{61}$ do corpo através de penitências e abstinências, o que era prática bastante relevante no período moderno, como demonstrou William Martins ${ }^{62}$ especialmente para a construção de modelos de santidade. Seja qual for o posicionamento de um autor ou o entendimento de um leitor, a identificação da gula como um pecado e vício a ser combatido se deve não somente ao imaginário religioso, mas à própria tentativa de normatização das práticas alimentares e controle do corpo e do comportamento do fiel na cultura religiosa católica, bastante presente na primeira metade do Setecentos português.

\section{Modos de evitar e remediar a gula}

Várias foram as recomendações dos autores religiosos aos fiéis que porventura se vissem tentados pela gula, tanto em termos de evitar (prevenir), como de recuperar (remediar) os sujeitos gulosos.

\footnotetext{
${ }^{60}$ SANTA THERESA, Paulo de. Flagello do peccado. Lisboa: Officina Antonio Pedrozo Galram, Tomo I, 1734; Tomo III, 1738, p. 372. O jejum como prática a repreender a gulodice e a sujeitar o apetite sensual às "leis do espírito" figuravam entre as instruções de Francisco de Sales no início do século XVII (SALES, Francisco de. Introdução à vida devota. Nova edição revista e prefaciada com prólogo do Padre Gonçalo Alves. Porto: Livraria Catholica Portuense, Centro de Propaganda religiosa em Portugal e Brazil, s/d [1609], p. 319).

${ }^{61}$ Embora não houvesse uma compreensão una e contínua sobre o pecado da gula ao longo do período moderno, é importante destacar que havia tanto um diálogo constante com os autores clássicos da Igreja, quando uma própria atualização de concepções que circulavam desde o século XVI. Assim, alguns argumentos eram sustentados a partir da referência aos santos padres e filósofos da antiguidade, com citação de diversos exemplos retirados de Santo Agostinho, Santo Ambrósio, São João Crisóstomo, São Gregório, São Bernardo, entre outros. E publicações como a do padre Luís de Granada, num clamar religioso próprio de sua época, a defender veementemente um modelo de "homem reformado", esforçando-se por alertar o leitor sobre os sofrimentos, castigos e tormentos de consciência que, no futuro, padeceria a alma em função dos regalos e deleites desordenados consumidos "nos anos passados" (GRANADA, op. cit., p. 324). ${ }^{62}$ MARTINS, William de Souza. Modelos de santidade no Período Moderno segundo o Portugal ilustrado pelo sexo feminino (1734). In: FLECK, Eliane Cristina Deckmann; DILLMANN, Mauro (Orgs.). o Universo letrado da Idade Moderna: escritoras e escritores portugueses e luso-brasileiros, séculos XVI-XIX. São Leopoldo: Oikos/Unisinos, 2019, p. 247.
} 
Em termos práticos e cotidianos, as instruções passavam pelas seguintes observações: a diminuição da ingestão de comidas e bebidas; a moderação, a modéstia e a parcimônia no consumo, sem exceder em quantidade; a precaução quanto ao comer fora dos horários das refeições; o cuidado em manter o contentamento e o apetite ao que se dispunha à mesa. Comer e beber pouco, moderadamente, com delicadeza e apenas o necessário eram instruções que vigoravam em todos os manuais pesquisados. A ideia era ingerir apenas o suficiente para a manutenção da saúde, mesmo que ainda restasse a fome e o desejo de comer. Nesse ponto, a máxima de Sócrates, replicada por Antônio Vieira, ${ }^{63}$ no século XVII, comer para viver, e não, viver para comer se fazia presente. E ainda o respeito à hora das refeições despontava como importante mecanismo de guarda da virtude da temperança, pois sem causa ou necessidade não haveria de ser ingerida qualquer comida ou bebida. ${ }^{64}$

Para o universo infantil, como demonstrou Ripe, ${ }^{65}$ os adultos eram responsáveis por não permitir o "muito comer", a lisonja do gosto e a incitação ao pecado, embora o pecar pelo consumo em momentos aleatórios parece ter sido prática reconhecida como relativamente natural. 0 método sugerido pelo religioso Manoel Dias de Sousa (1753-1823) para saciar as crianças em situações de fome pode ser inusitado ao olhar contemporâneo:

Não se permita às crianças o muito comer, nem mais vezes do que quatro ao dia, e quando peçam de comer fora das horas ordinárias, não se-lhes dê cousa, que lisonjeando o gosto, as incite a comer sem necessidade; pois muitas vezes o pedem somente por apetite: pode dar sê-lhes uma fatia de pão grosseiro, e duro, porque se verdadeiramente tiverem fome não deixarão de o comer, e se a não tiverem é melhor que não comam. ${ }^{66}$

Adultos e crianças deviam efetivamente se manterem disciplinados em relação ao consumo quase exclusivo durante as refeições. E, além disso, cabia ao sujeito cristão levantar da mesa sem estar satisfeito, logo, ainda com fome. Essa máxima foi muito difundida nos livros religiosos, com algumas nuances, e também utilizado pelos autores com referência a médicos para sustentação

\footnotetext{
${ }^{63}$ VIEIRA, op. cit., p. 553.

${ }_{64}$ “Comer fora das horas ordinárias, sem necessidade por pouco que seja, é cousa bem culpável, e prejudicial para a virtude" (ARANHA, op. cit., p. 189; GAUGÉRICO, op. cit., p. 154). Cabe ressaltar que entre as classes populares, vivia-se "do limiar da fome à simples subsistência" (BACELAR, Jeferson; MOTT, Luiz. A comida baiana: cardápios de um prisioneiro ilustre (1763). Salvador: Edufba, 2016, p. 47).

${ }^{65}$ RIPE, op. cit., p. 132.

${ }^{66}$ Apud RIPE, op. cit., p. 132.
} 
do argumento. Tal é a postura de Boaventura Aranha ao dizer: "os médicos aconselham que sempre se levante o homem da mesa com fome e disposição de poder tornar a comer" ${ }^{67} \mathrm{Ou}$ ainda essa outra passagem: "não é necessário comer a fartar, mas levantar da mesa sempre com apetite; o que também é conforme ao aviso dos Medicos" ${ }^{68}$ Na tentativa de garantir a moderação e a modéstia à mesa, os autores ou lembravam os leitores sobre os sofrimentos de Cristo ou dos perigos do inferno, incitando os leitores a reprimirem o apetite e o deleite do gosto. ${ }^{69}$

O respeito aos momentos das refeições e a manutenção de um estado de relativa fome era, pelos religiosos, remetidos também a situações confortáveis de condição física e de saúde do corpo. Boaventura Aranha, por exemplo, como já indicado por outros autores, referia apenas a importância do comer e beber para o "sustento da natureza", já que a comida seria a "medicina para conservar a vida". ${ }^{70} \mathrm{Ou}$, em outras palavras, como referia um Beneditino anônimo em 1751, tomar o alimento "para adquirir forças", renunciando ao "gosto natural". ${ }^{71}$

Então, para evitar o pecado da gula havia a necessidade de consideração da dietética, do alimento como remédio que deveria ser ingerido metodicamente para curar as doenças do corpo. ${ }^{72}$ Os cristãos haveriam de usar os alimentos como se usassem da medicina, um conselho de Santo Agostinho ${ }^{73}$

\footnotetext{
${ }^{67}$ ARANHA, op. cit., p. 189.

${ }^{68}$ GAUGÉRICO, op. cit., p. 155.

${ }^{69}$ ANÔNIMO, op. cit., p. 426.

${ }^{70}$ ARANHA, op. cit., p. 188.

${ }^{71}$ ANÔNIMO, op. cit., p. 425.

${ }^{72}$ A especificação da cura de doenças por meio de regimes alimentares não foi ponto de preocupação dos religiosos, mas o era da medicina e o melhor exemplo é Âncora Medicinal, de Francisco da Fonseca Henriques (1ª edição, 1721). Análises nesse sentido, veja-se ALGRANTI, Leila Mezan. Saberes culinários e a botica doméstica: beberagens, elixires e mezinhas no Império português (séculos XVI-XVIII), Sceculum - Revista de História, n. 27, p. 13-30, dez. 2012b; NOGUEIRA, André Luís L. "Comida como remédio": agentes de cura e receitas médicas no setecentos. Revista do Arquivo Geral da cidade do Rio de Janeiro, n. 14, p. 19-40, 2018; VIOTTI, Ana Carolina. Da mesa à mesinha, a alimentação como remédio (século XVIII). In: ALGRANTI, Leila Mezan; MACÊDO, Sidiana da Consolação (Orgs.). História e Alimentação: Brasil, séculos XVI-XXI. Belém: PakaTatu, 2020, p. 46-69; FLECK, Eliane Cristina Deckmann; DILLMANN, Mauro. "Esta receita é maravilhosa": saberes e práticas curativas na literatura médica publica em Portugal na primeira metade do século XVIII, História (São Paulo), 2021 (no prelo).

${ }^{73}$ No século IV, ao refletir sobre a gula, Santo Agostinho, em Confissões, assinalava a necessidade dos jejuns "reduzindo o corpo à escravidão", pois o motivo do comer e do beber residia na saúde e, assim, os alimentos deviam ser consumidos apenas como remédio. O prazer da alimentação era perigoso, sendo necessário combater esta "delícia” (AGOSTINHO, Santo, Bispo de Hipona, 354-430. Confissões. Trad. J. Oliveira e A. Ambrósio de Pina. Petrópolis: Vozes, 2011, p. 243-244). No século XVIII, João Franco dizia que as únicas delícias permitidas eram as “delícias do céu” (João Franco, Vida portentosa da serva de Deus D. Thomazia de Jesus, terceira professa da Venerável Ordem de S. Domingos. Lisboa: oficina de Miguel Manescal da Costa, 1757, p. 16-18).
} 
retomado na literatura religiosa. Daí a importância de tomar o alimento "como se tomam os remédios, isto é, com medida, sem exceder os justos limites". ${ }^{74}$ Comer apenas o necessário para o sustento ou para a cura era argumento legitimado na medicina e uma obra encarada como proveitosa para a mortificação do sentido do gosto. ${ }^{75}$

Outro aspecto preconizado e que devia ser observado era o modo de comer. Gaugério recomendava não comer com demasiada pressa "como se quisesses engolir tudo", o que seria um "modo brutal e pouco decente à dignidade humana”, mas sim, tomar a refeição com a modéstia necessária de quem "está na presença de Deus". ${ }^{76}$

Se existiam as recomendações práticas que diziam respeito ao quê, quando e como comer e beber, também havia aquelas de caráter sentencial e moral. Assim, um modo eficaz de evitar a gula estava na prática da abstinência como um meio de evitar a tentação do gosto e de progredir espiritualmente. ${ }^{77}$ Praticá-la, portanto, seria uma forma de triunfar diante das tentações, de modo que, conforme Boaventura Aranha, ${ }^{78}$ aqueles que não exercitassem essa virtude, não poderiam "dar passo" para "a vida espiritual". Para esse religioso, ao lado de outros sentidos exteriores (visão, audição, olfato, tato), o gosto deveria ser mortificado para exercitar a vitória da virtude da temperança e da abstinência. ${ }^{79}$ Embora fosse prática recomendada a todos os cristãos, cabia principalmente aos membros do clero secular e aos religiosos que viviam enclausurados - em busca de aperfeiçoamento da vida espiritual, das vivências religiosas e das experiências pessoais - um efetivo empenho na privação de alimentos tidos como saborosos ${ }^{80}$ Entre as recomendações estava a de deixar

\footnotetext{
${ }^{74}$ ANÔNIMO, op. cit., p. 426.

${ }^{75}$ ARANHA, op. cit., p. 185.

${ }^{76}$ GAUGÉRICO, op. cit., p. 155.

${ }^{77}$ Aos religiosos, a privação e a recusa alimentar voluntária era "meritória na economia da salvação" e um importante acesso ao caminho da santidade, de modo que a mesa - a exemplo da ceia de Cristo - poderia ser "exemplo de edificação e de perfeição", e não apenas "um lugar de perdição" (QUELLIER, op. cit., p. 33-34). A busca pelos modelos de santidade no período moderno era marcada ainda por restrições alimentares muito mais rigorosas e/ou consumos de substâncias que hoje seriam consideradas insalubres, como percebeu William Martins ao analisar fontes de caráter hagiográfico, como relatos e cartas de bispos, freis e padres acerca de uma beata fluminense - Jacinta de São José - no século XVIII. Segundo Martins, o modelo de santidade orientado a partir de Trento buscava "incentivar como comportamento ideal a virtude heroica e a obediência à Igreja" (MARTINS, William de Souza. Práticas do corpo e conhecimento do além da beata fluminense Jacinta de São José (c. 1744-1754). In: ANDRADE, Marta Mega; SEDREZ, Lise; MARTINS, William (Orgs.). Corpo: Sujeito e Objeto. Rio de Janeiro, Ponteio, 2012, p. 167).

${ }^{78}$ ARANHA, op. cit., p. 188.

${ }^{79}$ Ibidem.

${ }^{80}$ No interior do universo eclesiástico o "comer delicado" era um dos doze abusos que destruíam a religião,
} 
sempre alguma cousa do que vos dá maior gosto, (...) privar-vos de alguma cousa em cada prato, e de deixar nele sempre algum bocado mais apetitível; comei de melhor vontade os comeres grosseiros, que os que vos parecem mais esquisitos e mais delicados. ${ }^{81}$

Afora deixar de comer os alimentos mais saborosos, a prática do jejum passava por alguns alertas, afinal "não é boa a abstinência que ao depois para em demasiada fartura". ${ }^{82}$ Portanto, mais valia "comer pouco e andar sempre faminto" do que realizar um "jejum de três dias", ${ }^{83}$ capaz de promover um apetite desordenado após esse período. ${ }^{84}$ Tinha valor maior os jejuns moderados "para que o estômago não enfraqueça", uma vez que a temperança seria o mais proveitoso para o corpo e a alma. Da mesma forma, o "comer com o pensamento" era um grande erro cometido por aquele que "prepara as iguarias de um para outro dia" movido pela "satisfação da sua gula". ${ }^{85}$ A abstinência, considerada a "mestra da continência e da pureza", traria efeitos morais práticos para a conduta e os sentimentos: "nos faz humildes, castos, sóbrios, virtuosos, puros, compassivos, brandos, caritativos, prudentes e acautelados”. ${ }^{86}$ Para os mais piedosos ou com aspirações à santidade, porém, a maior mortificação estava numa abstinência contínua vinculada à escolha de alimentos pouco apreciados e de uso de ingredientes amargos ou impuros, como pão escuro ou bolorento, água, mingau e algum legume, como rabanete..$^{87}$

como alertava Manoel Bernardes (op. cit., 1728, p. 42) apoiado em São Bernardo e no jesuíta alemão Jeremias Drexel. Segundo Bluteau (1728, p. 48), o "gosto delicado" acabava por despertar a "gulosina de muitos", pois "tem ensinado a não fazer caso do peixe, a quem chamam lobo do Rio". o peixe era alimento de caráter popular e a carne de vaca, dos altos segmentos e dos conventuais, segundo Leila Algranti (op. cit., 2012a, p. 205-210).

${ }^{81}$ ANÔNIMO, op. cit., p. 426.

${ }^{82}$ Instrução similar já constava em Introdução à vida devota, de Francisco de Sales, no século XVII: "pela experiência sei que (...) a gente moça, caindo em enfermidades, por jejuns excessivos, se tornam facilmente para o regalo" (SALES, op. cit., p. 320).

${ }^{83}$ BARBA RICA, op. cit., p. 02.

${ }^{84}$ Tais instruções deveriam ser convenientes para religiosos/as conventuais que conviviam com alternância entre "dias magros" e "dias gordos". Leila Algranti (op. cit., 2012a, p. 206) demonstrou que as religiosas do Convento dos Remédios, de Braga, jejuavam certos dias da semana, além dos obrigatórios (Quaresma, Semana Santa, Advento [período que antecede o natal]), quando a dieta magra excluía carne; os "dias gordos" oportunizavam a ingestão de carnes de vaca, de porco e de aves.

${ }^{85}$ BARBA RICA, op. cit., p. 02.

${ }^{86}$ Ibidem, p. 23.

${ }^{87}$ MARTINS, op. cit., 2012; QUELLIER, op. cit., p. 91; GÉLIS, Jacques. O corpo, a Igreja e o sagrado. In: VIGARELLO, Georges (Dir.). História do corpo. V. 1: Da Renascença às Luzes. Trad. Lúcia Orth; revisão Ephraim Alves. $2^{a}$ ed. Petrópolis: Vozes, 2008, p. 56-58. 
Outros eficientes mecanismos para evitar a gula durante as refeições eram a oração e a fé, uma vez que tal pecado poderia ser considerado como "um dos mais perigosos inimigos que tendes para combater", já que a tentação pela comida e bebida ganhavam dimensão maior quando o sujeito estava à mesa. O beneditino anônimo dizia ser necessário estar "sempre armado contra os seus assaltos"; para tanto, o cuidado em "invocar o socorro do Senhor" e do "santo anjo" em oração era imprescindível ${ }^{88}$ para "escapar cuidadosamente dos laços que vos arma, quando estais na mesa" ${ }^{89} 0$ exercício da fé cristã ainda exigia de seus praticantes outros comportamentos como o de evitar queixas sobre a comida e bebida preparadas ou disponíveis ao consumo, conduzir as refeições acompanhadas, se possível, da realização de lições espirituais e dar "graças a Deus" ao "fim da comida", solicitando o perdão divino..$^{90}$ Ainda que fosse amplamente recomendada no universo cristão e incessantemente prescrita nas literaturas religiosas, a oração no momento das refeições, um caro exemplo bíblico da vida de Cristo, ${ }^{91}$ era costume nem sempre praticado entre os católicos, como diz ter observado Gaugérico: “Eu que estou traduzindo este livro não me posso abster de não estranhar um mau costume (...) familiar que tenho notado em diversas terras e cidades, aonde (...) não se benze a mesa". ${ }^{92}$

Em síntese, a ideia de seguir os conselhos dos pregadores, dos confessores e dos livros ${ }^{93}$ - porta-vozes da vontade de Deus, da "lei eterna" e da Igreja - apresentava-se como eficaz meio de imprimir um autocontrole na vigia da gula, pois como já destacado, só seria permitido o comer e o beber enquanto

\footnotetext{
${ }^{88}$ Embora as obras não especifiquem o caráter da oração - se mental ou vocal - vale referir que foi a literatura espiritual publicada a partir do século XVI na Península Ibérica que difundiu entre os estratos urbanos entusiasmados com a devotio moderna a importância da oração (mental), da busca por Deus através do Cristo revelado nas escrituras e de certa tentativa de união com a divindade. Mesmo que com diferentes autores, representando distintas espiritualidades, ora mais focadas na imaginação, ora na meditação ou ainda na contemplação, tratava-se, em geral, da busca de purificação moral por meio de exercícios do corpo e da alma nas virtudes ideais do "cristão exemplar" (SÁNCHEZ, op. cit., p. 126-127), elementos que tiveram forte repercussão nas publicações dos séculos XVII e, pelo menos, primeira metade do XVIII.

${ }^{89}$ ANÔNIMO, op. cit., p. 424.

${ }^{90}$ GAUGÉRICO, op. cit., p. 156.

${ }^{91}$ A obra Guia de Pecadores, do padre Granada - escrito no século XVI (1570), mas com ampla aceitação pelo público católico, de modo a ganhar grande circulação, sendo publicada inúmeras vezes ao longo do século XVIII - trazia no capítulo VIII o título "Remédios contra a gula", defendendo a imitação de Cristo como meio eficaz para remediar o perigoso vício.

${ }^{92}$ GAUGÉRICO, op. cit., p. 156.0 estranhamento do espanhol Gaugérico contrasta com a tradicional hábito de rezar à mesa, conforme percebe-se na pintura Retrato familiar a lo divino, de 1640, de anônimo sevillano, em que numerosa família faz oração diante da refeição, pedagogicamente apresentando a uma criança essa experiência de devoção no ambiente do lar, fora da fiscalização eclesiástica (SÁNCHEZ, op. cit., p. 129-130).

${ }^{93}$ CONCIENCIA, Manoel. A mocidade enganada, dezenganada. Lisboa: Officina Mauricio Vicente de Almeida, 1734, p. 391.
} 
necessário "para conservação da saúde e para o sustento da vida" ${ }^{94}$ caso contrário, os efeitos desse pecado poderiam ser negativos para um corpo físico sadio e uma vida cristã exemplar. 0 cristão deveria se reconhecer enquanto guloso para do vício se livrar; deveria "desenganar-se", fugir dos enganos provocados pelas tentações alimentares, para a consolidação de uma vivência religiosa virtuosa e salvífica, pois diante da gula, as advertências eram claras: "Quantos nesse mundo (...) tudo vendem e destroem para comer e beber, sem advertir o mal que fazem não só ao corpo, mas também ao espírito". ${ }^{95} \mathrm{O}$ que se percebe, assim, nessa literatura religiosa, é a utilização de estratégias discursivas capazes de criar em seus fiéis mecanismos de autocontrole, de disciplina das próprias vontades, não somente pelo benefício da manutenção de um corpo sadio, mas pelo medo dos efeitos espirituais que o pecado da gula poderia trazer, comprometendo o seu processo de salvação. Vejamos, então, quais eram esses males causados ao corpo e à alma.

\section{Os efeitos da gula no corpo e na alma}

o pecado da gula carregava várias consequências negativas ao corpo e à alma do cristão e os religiosos se empenhavam em alertar para seus potenciais perigos, tais como a debilidade da saúde, o prejuízo das virtudes (especialmente da temperança e da sobriedade), o aumento dos vícios, das maldades e das malícias, o acesso a outros pecados (especialmente a luxúria), o tormento demoníaco e a perda da razão. O padre Joam Barba Rica, ${ }^{96}$ por exemplo, alertava sobre o quanto "as demasias da gula e os regalos enchem a alma de vícios", incluindo as bebedices, causadoras de contendas, ira e soberba. ${ }^{97}$

0 excesso de bebidas e o estado de embriaguez, especialmente associados e resultantes do consumo de vinho, ${ }^{98}$ mereceu atenção especial de vários

\footnotetext{
${ }^{94}$ BARBA RICA, op. cit., p. 31.

${ }^{95}$ SANTA THERESA, op. cit., p. 24.

${ }^{96}$ BARBA RICA, op. cit., p. 09 e 41.

${ }^{97}$ No século XVII, o padre Antônio Vieira (2006 [1677]) referia como efeitos da intemperança do comer, as seguintes relações de causa e efeito: intemperança-crueldades; cruezas-confusão e discórdia de humores; humores discordes- doenças; doenças-morte.

${ }^{98}$ A produção de vinho português com competência técnica ocorria desde a Idade Média, fazendo, inclusive, exportação do produto ao longo do período moderno (RENOUARD, Y. O grande comércio do vinho na Idade Média. Revista de História (USP), v. 6, n. 14, p. 301-314, 1953, p. 312). O consumo pela Europa medieval era intenso, mesmo em festas e espaços sagrados. Cumpre lembrar que Huizinga (op. cit., p. 261) registrou que em Estrasburgo, já no século XV, servia-se anualmente "1.100 litros de vinho para aqueles que passassem a noite de São Adolfo na igreja 'em vigília e em oração”".
} 
autores religiosos, porque produziria sujeitos "alienados dos sentidos". ${ }^{99}$ Os escritores apresentavam as marcas físicas identificáveis naqueles que bebiam exageradamente. O padre Joam Barba Rica, citando São Basílio, dizia que o "homem alienado do vinho" apresentaria "olhos pisados, com cor pálida, e espírito pesado e triste, a língua balbuciante, a voz confusa, os pés trêmulos e embaraçados". ${ }^{100}$ E o padre Santa Theresa constatava que o homem embriagado, mesmo o mais forte e robusto, caía e andava como um tonto.$^{101} \mathrm{O}$ estado de ebriedade também era marcado, nas palavras de Pedro de Santa Clara, por "fantasia turbada", "vômito", "titubes da língua" e "vista (...) empoada". ${ }^{102} \mathrm{O}$ excesso dessa bebida seria, dessa forma, muito danoso "para o espírito e para o corpo", ${ }^{103}$ de modo a "a perder a muitos, metendo-os em grandes perigos da alma e do corpo". ${ }^{104}$ Esses discursos, carregados de uma caracterização negativa do sujeito embriagado, incitava ao fiel o sentimento de vergonha e sua consequente possibilidade de ser visto como escândalo e perigo social; aguçavam também sentimentos de temor ao desprestígio, uma vez que possuir a racionalidade duvidada por indicação de "ausência" ou "falta" de razão se tornava mecanismo de desqualificação social. ${ }^{105}$

Essas descrições dos efeitos físicos da embriaguez a partir do vinho, não eliminavam o reconhecimento das suas qualidades e consequências positivas, especialmente para a velhice. Assim, a recomendação era de que o vinho fosse consumido por motivos de evidentes situações de enfermidades, como as debilidades da idade avançada ou simplesmente como um modo de temperar

\footnotetext{
${ }^{99}$ Para a França, Quellier (op. cit., p. 96) refere a embriaguez como um flagelo no fim do Antigo Regime, sendo considerado por autores cristãos como o verdadeiro, perigoso e escandaloso pecado da gula.

${ }^{100}$ BARBA RICA, op. cit., p. 38.

${ }^{101}$ SANTA THERESA, op. cit., p. 12.

${ }^{102}$ SANTA CLARA, op. cit., p. 356.

${ }^{103}$ ARANHA, op. cit., p. 189.

${ }^{104}$ BARBA RICA, op. cit., p. 25. Certo é que os médicos portugueses, à época, traziam outras explicações sobre os prejuízos do vinho ao corpo, além de suas benesses curativas. 0 médico Teotonio Pessana (pseudônimo de José Antônio da Silveira) afirmava em obra de 1741: "ninguém duvida que o abuso do vinho produz paresia, causa impotências, faz tremores e outras muitas queixas" (Apud PEREIRA, Milena da Silveira. Uma nova bebida para curar em terras lusas (século XVIII). In: FRANÇA, Susani Silveira; VIOTTI, Ana Carolina (Orgs.) Cuidar do espírito e do corpo entre o velho e os novos mundos (séculos XIII-XVIII). São Carlos: Eduscar, 2019, p. 402). Para o médico Francisco da Fonseca Henriques, em Âncora Medicinal (op. cit., p. 431) afora todos os benefícios do vinho - a depender da idade e do grupo social - alertava para os danos do excesso: "esturra os alimentos no estômago, debilita o calor natural, faz muita sede, e intemperanças nas entranhas, aquenta muito e faz ferver a massa do sangue, causa hidropisias, não só timpânicas (...), faz acidentes epiléticos, estupores, paralisias, apoplexias, gota artética, reumatismos, tremores de mãos, fastio, vômitos, pleurises, e outras inflamações internas e externas, e outros muitos danos".
}

${ }^{105}$ RIPE, op. cit., p. 146. 
a água consumida durante as refeições. Ainda assim, os aconselhamentos estavam pautados pela abstenção do vinho para os que "não tem conhecida necessidade", especialmente para os mais moços, para quem o vinho seria "veneno". ${ }^{106}$ Esse efeito medicinal do vinho era reconhecido entre os autores dos manuais religiosos, como Barba Rica que afirmava ter sido a bebida criada "para remédio, e não para vício", pois "Deus criou para medicina". ${ }^{107} \mathrm{O}$ uso do vinho pela farmacopeia lusitana era amplamente conhecido, a contar pelo sucesso do vinho à base de quina, chamado de "água de Inglaterra", utilizado em Portugal no tratamento contra a malária durante todo o século XVIII. ${ }^{108}$

A ingestão excessiva, porém, conduzia à embriaguez e esta enevoaria o juízo, alterando o comportamento e tornando qualquer senso de racionalidade suscetível às insolências, aos falatórios e aos tumultos. ${ }^{109}$ Pedro de Santa Clara, explicava que a ebriedade era o "excesso no beber" por deleite, a embriaguez, seguida da perda do uso da razão e da plena distinção entre o bem e o mal. ${ }^{110}$ Essa preocupação dos religiosos com a alienação do juízo e da razão foi constantemente reforçada: "De tal sorte aliena o discurso, que o homem se não conhecer a si mesmo, e fica tão alienado, que não sabe aonde vai". ${ }^{111}$ Além de comprometer o discurso, a lucidez, a razão, o vinho - consumido em excesso - era "veneno" por excitar, nutrir e aumentar a luxúria, a tentação pelo deleite sexual. ${ }^{112}$

Diversos religiosos utilizaram as consequências negativas da gula, para conjugar discursivamente os efeitos prejudiciais ao corpo e à alma. $\mathrm{O}$ excesso de comidas e bebidas poderia, segundo o padre Manoel Conciencia, ${ }^{113}$ trazer "pontada" aguda nas costas, estômago revolto, vômitos, ânsias e convulsões, e no extremo, o "excesso da gula" poderia causar fluxos de sangue pela boca e apoplexia. O estômago cheio traria o padecimento de "cruezas", indigestões" e privações do sono. ${ }^{114} \mathrm{E}$ o excesso de bebida, especialmente do vinho,

\footnotetext{
${ }^{106}$ ARANHA, op. cit., p. 189.

${ }^{107}$ BARBA RICA, op. cit., p. 25-26.

${ }^{108}$ FIGUEIREDO, Patrick. A “Água de Inglaterra” em Portugal. In: BASTOS, Cristiana; BARRETO, Renilda (Orgs). A circulação do conhecimento: medicina, redes e impérios. Lisboa: Imprensa de Ciências Sociais (UL), 2012, p. 113.

${ }^{109}$ BARBA RICA, op. cit., p. 37.

${ }^{110}$ SANTA CLARA, op. cit., p. 357.

${ }^{111}$ BARBA RICA, op. cit., p. 26.

${ }^{112}$ Vale lembrar que o vinho fazia parte do ritual litúrgico de celebração do "corpo de Deus" ou da "sagrada comunhão”, e seu consumo, ainda que simbólico, era prática comum entre os católicos.

${ }^{113}$ CONCIENCIA, op. cit., p. 205.

${ }^{114}$ Ibidem, p. 90.
} 
enfraqueceria o corpo e prenderia a alma, perturbando o entendimento e aumentando a ira: "desperta o furor e acende as chamas da concupiscência". A demasia no beber seria por certo acompanhada da lascívia ${ }^{115}$ e o vinho era o principal responsável por estes efeitos noviços porque traria consigo uma "singularíssima torpeza", de modo que merecia um "discurso separado". ${ }^{116} \mathrm{O}$ guloso, especialmente o embriagado, estava propenso às culpas, ao crime e aos vícios corporais e morais condenáveis, segundo os escritos religiosos, e Barba Rica referia que o excesso do beber conduziria aos pecados mais desonestos como adultérios e homicídios. ${ }^{117}$

Se o estado da bebedice era uma evidência óbvia do consumo excessivo das bebidas alcoólicas, outro efeito mais imediato ou mais facilmente reconhecível do pecador guloso estava no excesso de gordura corporal, ${ }^{118}$ embora esse tenha sido um enunciado pouco mencionado e explorado nas fontes consultadas. O corpo demasiadamente pesado e o ventre indigesto eram encarados como consequência física do consumo alimentar mal realizado, daí a necessidade de perceber com atenção a quantidade de comida e bebida ingerida, evitando o (mau) hábito do abuso. ${ }^{119}$

Além do aspecto físico, ${ }^{120}$ destacavam-se determinados comportamentos e sentimentos no sujeito guloso, tal como Pedro de Santa Clara fez questão

\footnotetext{
${ }^{115}$ BARBA RICA, op. cit., p. 25-26.

${ }^{116}$ Ibidem, p. 27.

${ }^{117}$ Ibidem, p. 26. 0 padre Manoel Conciencia (op. cit., p. 123) apontava para uma sequência contínua entre gula, sensualidade, adultério e homicídio.

${ }^{118} \mathrm{Em}$ explicação científica da época, o corpo gordo também poderia ser resultado de um descompasso dos humores, especialmente em pessoas com temperamento fleumático que trariam como "defeitos" a dormência, a preguiça e a gordura corporal (DELUMEAU, op. cit., p. 323-325). 0 alerta para a preguiça e a indolência que os prazeres dos sentidos provocavam no corpo estava presente na obra voltada ao público infanto-juvenil As aventuras de Telêmaco, do francês François Fénelon - publicado em 1699, com primeira edição portuguesa em 1776 -, pois os contentamentos momentâneos com guloseimas, como caramelo, açúcar cristalizado, compotas, caldas, e com outros alimentos picantes, como linguiças, presuntos e guisados, logo cansariam e degradariam a moral do homem (QUELLIER, op. cit., p. 66; ABREU, Márcia, et. al. Caminhos do romance no Brasil: séculos XVIII e XIX. São Paulo, Universidade de Campinas, s/ed., 2005, p. 16 Disponível em http://www.caminhosdoromance.iel.unicamp.br/estudos/ensaios/caminhos.pdf. Acessado em 22/09/2020.

${ }^{119}$ ARANHA, op. cit., p. 190.

${ }^{120}$ As compreensões médicas sobre os efeitos físicos resultantes da ausência de temperança alimentar são inúmeros e não cabem nos limites desse texto. 0 português Fonceca Henriques, em 1721, alertava que os mais ricos, por disporem de assados, fricassés, guisados, presuntos, entre outros, mais facilmente estragavam seus estômagos e perdiam a saúde (Apud FLECK, Eliane Cristina Deckmann; DILLMANN, Mauro. "Para a alma, \& para o corpo he a gula o mais mortal peccado": discursos religiosos e médicos sobre os entendimentos e os efeitos do consumo alimentar exagerado, Portugal, século XVIII. Varia História, vol. 37, n. 74, 2021, p. 545). O médico italiano Bernardo Ramazzini, em 1710, alertava que nobres e príncipes, geralmente de vida ociosa, deveriam comer carnes mais leves como aves que voam e carneiro, para
} 
de detalhar. Tratava-se das cinco "filhas da gula", que seriam a estupidez, a alegria imoderada, o multiloquio, a jocarrice e a imundícia. A estupidez consistia em não poder orar devido ao comer e beber desordenado, a inaptidão em "obrar o necessário para a sua salvação"; a alegria imoderada era o movimento em direção a "cantigas obscenas, atos torpes, saltos e danças desonestas"; a jocarrice seriam "uns gestos que provém da falta da razão, os quais assim como não podem coibir as palavras, (...) não podem impedir os movimentos exteriores"; a imundícia era entendida como "a expulsão de qualquer superfluidades, especialmente a expulsão seminis”. A única não explicada pelo autor foi o multiloquio, mas que possivelmente estaria vinculado à ideia de falar muito, da múltipla conversação. ${ }^{121}$

Por fim, um dos efeitos mais graves da gula na mentalidade religiosa da época estava na condenação da alma do guloso. O padre Manoel Conciencia dizia que os condenados seriam aqueles que fugiam à mortificação das paixões e de vários outros "erros" que cometiam em vida, pois "só queriam regalos e passatempos: só queriam fomentos da gula e da vaidade: só queriam gostos, alegrias, e o deleite dos apetites, e criaturas". ${ }^{122} \mathrm{O}$ alerta do padre Conciencia fazia perceber que a gula podia ser combatida, e o pecador, desenganado. Mas eram taxativos - e enternecedores, especialmente aos olhos dos mais incrédulos no século XVIII - quanto ao destino da alma daqueles que persistiam no pecado, evitando se emendar na graça divina, a exemplo do padre Jozé Trindade, que em 1764 afirmava: "Ah pecadores dados aos mimos, e regalos, à gula, e aos gostos da carne! Aparelhai vossos corpos para o fogo dos infernos, onde sereis assados pelo demônio". ${ }^{123}$

garantirem o bem-estar e a saúde (Apud ALGRANTI, op. cit., 2012a, p. 210-211). No século XVII, tratados de dietética que circulavam na França anunciavam que o consumo frequente de "carne de boi" originava diversas doenças aos melancólicos, como câncer, febre, inchação do baço e hidropisia, embora os pratos com essa carne tenham se multiplicado no decorrer do século XVII e XVIII (FLANDRIN, Jean-Louis; MONTANARI, Massimo. História da Alimentação. Trad. Luciano Machado e Guilherme Teixeira. São Paulo: Estação Liberdade, 1998, p. 670-671).

${ }^{121}$ SANTA CLARA, op. cit., p. 358-359. O autor não refere o significado de multiloquio, provavelmente por esquecimento/descuido.

${ }^{122}$ CONCIÊNCIA, op. cit., p. 38.

${ }^{123}$ TRINDADE, op. cit., p. 242. Os religiosos eram bastante engenhosos na descrição dos tormentos infernais. Manoel Conciencia (op. cit., p. 389) dizia que "as demasias da sua gula continuadas por todo o dia em bebidas, e manjares tão preciosos para o gosto, como nocivos à saúde, pagará com raivosa fome, e sede, com féis e absintos amargosíssimos". 


\section{Considerações finais}

Os discursos religiosos sobre a gula e seus efeitos estavam amparados em códigos culturais específicos da compreensão católica a respeito do comportamento ideal, que moldavam os entendimentos sobre a necessidade de vida virtuosa do bom cristão no período moderno, especialmente no fervorosamente católico reino de Portugal do início do século XVIII. Assim, as imagens codificadas da gula passavam pela vinculação do comer e do beber com a idealização dos sensos de prazer do gosto - palatável ou sexual, pois facilmente comparável à luxúria e ao comportamento libidinoso - que deveriam ser evitados e combatidos, pois eram potenciais mecanismos desencadeadores dos mais condenáveis pecados. A prevenção ou recuperação do guloso se guiava por compreensões espirituais, com sutil diálogo com a ciência médica da época - desde que sem contradição, apenas como complementação discursiva - amparados em códigos espirituais (abstinência, jejum, oração, fé) e em códigos profanos (moderação, precaução, contentamento, diminuição de ingestão alimentar).

Neste artigo, buscamos compreender como os autores religiosos estavam interessados na gula e instruíam os leitores na medida em que se interrogavam sobre a natureza e as consequências do ser "glutão". Pecar pela gula não estava relacionado direta e exclusivamente com o consumo em si de comidas e bebidas e nem mesmo ao desejo/vontade de comê-las, mas sim, aos modos vorazes, curiosos, esquisitos e exagerados, capazes de prejudicar a saúde, a razão e o juízo sobre o caminho da salvação. Havia alguma recorrência de caráter científico-médico nas explicações, que vinculavam a ingestão de alimentos apenas à necessária conservação da saúde, seja como nutrição básica, seja como medicamentosa para enfermidades, ao identificar comida enquanto remédio.

Os manuais analisados, como buscavam alcançar os mais comuns fiéis, as pessoas leigas, eram moderados na consideração dos mecanismos de aquisição da virtude da temperança, especialmente quando comparados ao rigor esperado daqueles que desejavam atingir ideais de santidade, como demonstrou William Martins (2012). Mesmo assim, apetites e gostos para apreciação e deleite com sabores e manjares foram amplamente reprimidos pelos religiosos por serem considerados prazeres momentâneos quando comparados à eternidade da alma.

Este era o principal direcionamento das considerações a respeito da gula, de modo que as maiores delícias para o sentido do gosto seriam aquelas 
encontradas no "céu". Essa associação do reino dos céus a um banquete ou à abundância alimentar, segundo Paula Dias aparecia em autores dos primeiros séculos do cristianismo e apelava aos anseios das pessoas comuns que lutavam por alimentos e fugiam da fome. ${ }^{124}$ Argumentos enfatizados na literatura religiosa que circulou em Portugal da primeira metade do século XVIII: a recompensa pelo jejum e controle alimentar estaria no além, num futuro mítico pautado ironicamente ainda em promessas de satisfação do "paladar dos corpos", pois como assegurou Manoel Conciencia, ${ }^{125}$ a boca e a língua seriam recreadas e continuamente gostosas, tal como alguém que se encontra numa magnífica mesa entre as maiores delícias imagináveis.

Tais argumentos representavam o ápice do esforço dos autores no combate à gula e ao exagero do consumo, especialmente para aqueles que tinham a mesa farta. Ao considerar que Portugal iniciava o século XVIII com a experiência de banquetes entre os membros da alta burocracia e da elevada hierarquia eclesiástica e com a divulgação de livros de receitas culinárias, ${ }^{126}$ torna-se compreensível o empenho dos autores nessa temática e a possível relevância que os discursos sobre a gula adquiriam entre os potenciais leitores. Somava-se ainda as "excentricidades gastronômicas" portuguesas, como destacou Castelo-Branco, ${ }^{127}$ com o aperfeiçoado cardápio de peixes, carnes, sumos, frutas e doces que, somados às requintadas especiarias compunham, certamente, tentadoras sopas, assados, recheios e sobremesas.

Defendido pela Igreja, o entendimento da cozinha enquanto espaço de preparação de alimentos para a satisfação das necessidades da vida, convivia lado a lado com o ideal de cozinha sofisticada, efeito da delicadeza, da preocupação com o sabor, da volúpia, do estímulo ao apetite, do aperfeiçoamento da digestibilidade, que o século XVIII português conheceu por influência francesa. ${ }^{128} \mathrm{Com}$ o desenvolvimento de concepções sobre funções gastronômicas que exaltavam os sabores, entende-se a recorrência dos religiosos em situar sua posição de condenação do comer além do necessário como pecado da gula, embora nem sempre a caracterização desse comer tenha sido homogênea, entre os autores consultados, para considerá-la como pecado capital.

\footnotetext{
${ }^{124}$ DIAS, Paula Barata. A linguagem dos alimentos nos textos bíblicos: sentidos para a fome e para a abundância, Humanitas, v. 60, 2008, p. 174.

${ }^{125}$ CONCIENCIA, op. cit., p. 445.

${ }^{126}$ CASTELO-BRANCO, op. cit., p. 111.

${ }^{127}$ Ibidem, p. 114.

${ }^{128}$ FLANDRIN, op. cit., 1998, p. 682.
} 
De todo modo, ao acionar a noção de pecado, os discursos religiosos-morais impulsionavam a disciplina social e normatizavam comportamentos, idealizando sujeitos enquanto devotos, saudáveis e obedientes. As formulações de descrições dos efeitos do comer e do beber exageradamente, de participação em banquetes, da demasia nos modos à mesa, dos sobrepesos dos glutões, das restrições alimentares, das necessidades de orações antes das refeições, dos riscos do escândalo e do perigo social promovidos pelas bebedices, entre outros fatores apresentados no texto, podem ser percebidos como discursos para que a sociedade cristã se autocontrolasse e se autovigiasse, conduzindo-se rigorosamente no caminho da fé.

Aos devotos, o contentamento deveria estar nas refeições e banquetes espirituais, mortificando-se e resistindo às delícias da mesa. Os discursos sobre o pecado da gula lembravam ao leitor os limites que deveriam se impor diante das vontades e dos desejos pessoais, já que tal pecar era provocado pelos impulsos ao deleite, pela tentação e pela conduta lasciva, cujas consequências variavam, em termos de prejuízo ao corpo e à alma, de enfermidades do estômago à perda da noção de direito ao "paraíso". As instruções realçavam um valor moralizante de caráter educativo, voltado a qualquer pessoa que facilmente poderia ser afetada pelas atitudes e pelo comportamento glutão, apresentando a possibilidade de alterar a satisfação do gosto pela da alma, no tempo vivido na terra ou no tempo do além, junto ao infinito da divindade.

\section{Fontes}

ANÔNIMO. Avisos e Reflexões sobre o que deve obrar hum religioso, para satisfazer ao seu Estado. Por hum religioso Benedictino da Congregação de S. Mauro. Tomo I. $4^{a}$ edição. Lisboa: Officina de Joseph da Costa Coimbra, 1751.

ARANHA, Boaventura Maciel. Exercicios admiráveis para os dias do recolhimento interior. $2^{\mathrm{a}}$ ed. Lisboa: Officina Antonio Pedrozo Galram, 1728.

BARBA RICA, Joam. Espelho monástico, e catholico. Coimbra: Real Collegio das Artes da Companhia de Jesus, 1756.

BERNARDES, Manoel. Nova Floresta. Tomo V. Lisboa: Officina Joseph Antonio da Sylva, 1728.

BERNARDES, Manoel. Luz, e Calor. Lisboa: Officina Miguel Deslandes, 1696.

BLUTEAU, Raphael. Vocabulario portuguez \& latino. Vols. IV e V. Coimbra: Collegio das Artes da Companhia de Jesus, 1728. 
BLUTEAU, Rafael. Primicias Evangelicas, ou sermoens, e panegyricos. Lisboa: Officina Miguel Deslandes, 1685.

BRILLAT-SAVARIN. A fisiologia do gosto. Trad. Paulo Neves. São Paulo Companhia das Letras, 1995 [1825].

BURTON, Robert. A Anatomia da Melancolia. V. II. Trad. Guilherme Gontijo Flores. Curitiba: Ed. UFPR, 2012 [1621].

CONCEIÇÃO, Manoel da. Escola de Penitência, e flagelo de viciosos costumes. Lisboa: Officina Miguel Deslandes, 1687.

CONCIENCIA, Manoel. A mocidade enganada, dezenganada. Lisboa: Officina Mauricio Vicente de Almeida, 1734.

FRANCO, João. Vida portentosa da serva de Deus D. Thomazia de Jesus, terceira professa da Venerável Ordem de S. Domingos. Lisboa: oficina de Miguel Manescal da Costa, 1757.

FRANCO, João. Mestre da Virtude, segunda parte do Mestre da Vida, que persuade a todas as criaturas de qualquer estado que sejam, o que é necessário para se salvarem, e o que hão de fazer para serem santos. Lisboa: Oficina dos herd. de Antonio Pedrozo Galvão, 1745.

GAUGÉRICO. Director Espritual, que ensina hum methodo fácil para viver santamente. Coimbra: Officina Antônio Simões Ferreyra, 1731.

GRANADA, Luís de. Guia de pecadores...Tomo II. Barcelona: Juan Sellent, 1792 [1570].

HENRIQUES, Francisco da Fonseca. Ancora medicinal para conservar a vida com saúde. Lisboa: Officina Miguel Rodrigues, 1731 [1721].

LIMA, Manoel. Ideas sagradas, e consagradas em vários Sermoens Panegyricos. Tomo I. Lisboa: Officina de Mathias Pereyra da Sylva \& Joam Antunes Pedrozo, 1720.

LOBO, Francisco Rodrigues. Corte na Aldeia. Introdução de Maria Ema T. Ferreira. Lisboa: Editorial Verbo, 2005 [1619].

RODRIGUES, Afonso. Exercícios de perfeição e virtudes cristãs. Tomo III. São Paulo: Cultor de Livros, 2017 [1609].

SALES, Francisco de. Introdução à vida devota. Nova edição revista e prefaciada com prólogo do Padre Gonçalo Alves. Porto: Livraria Catholica Portuense, Centro de Propaganda religiosa em Portugal e Brazil, s/d [1609]. 
SANTA CLARA, Pedro. Cathecismo, ou O Christão bem instruído. Lisboa: Officina Miguel Manescal da Costa, 1744.

THERESA, Paulo de S. Flagello do peccado. Lisboa: Officina Antonio Pedrozo Galram, Tomo I, 1734; Tomo II, 1736.

TRINDADE, Jozé. Ramalhete Espiritual composto com as flores dos doze sermoens Doutrinaveis, que no Reyno de Portugal pregou o insigne Orador Missionario Apostolico, o Veneravel padre Fr. Antonio das Chagas. Lisboa: Officina de Francisco Borges de Sousa, 1764.

VIEIRA, Antonio. Sermão da quarta dominga depois da Páscoa. Com comemoração do Santíssimo Sacramento. Pregado em S. Luiz do Maranhão, Revista Latinoamericana de Psicopatologia Fundamental, v. 9, n. 3, São Paulo, p. 538-564, Jul./ Set. 2006 [1677].

\section{Referências bibliográficas:}

ABREU, Jean Luiz. Nos domínios do corpo: o saber médico luso-brasileiro no século XVIII. Rio de Janeiro: Fiocruz, 2011.

ABREU, Márcia, et. al. Caminhos do romance no Brasil: séculos XVIII e XIX. São Paulo, Universidade de Campinas, s/ed., 2005, p. 01-22. Disponível em http:// www.caminhosdoromance.iel.unicamp.br/estudos/ensaios/caminhos.pdf. Acessado em 22/09/2020.

ALGRANTI, Leila Mezan. Refeições festivas e cotidianas em Portugal no século XVIII: as religiosas do Convento de Nossa Senhora dos Remédios (Braga). In: ANDRADE, Marta Mega; SEDREZ, Lise; MARTINS, William (Orgs.). Corpo: Sujeito e Objeto. Rio de Janeiro, Ponteio, 2012a, p. 203-220.

ALGRANTI, Leila Mezan. Saberes culinários e a botica doméstica: beberagens, elixires e mezinhas no Império português (séculos XVI-XVIII), Sceculum - Revista de História, n. 27, p. 13-30, dez. 2012b.

AGostinHO, Santo, Bispo de Hipona, 354-430. Confissões. Trad. J. Oliveira e A. Ambrósio de Pina. Petrópolis: Vozes, 2011.

ARAÚJO, Maria Marta L.; ESTEVES, Alexandra (Orgs.). Hábitos alimentares e práticas quotidianas nas instituições portuguesas. Braga: Diário do Minho, 2015.

BACELAR, Jeferson; MOTT, Luiz. A comida baiana: cardápios de um prisioneiro ilustre (1763). Salvador: Edufba, 2016. 
BRAGA, Isabel Drumond. Sabores e segredos: receituários conventuais portugueses da Época Moderna. Coimbra: Imprensa da Universidade de Coimbra, 2015.

CARVALHO, José Adriano de Freitas (Org.). Bibliografia cronológica da literatura de espiritualidade em Portugal, 1501-1700. Porto: Instituto de Cultura Portuguesa, 1988.

CASTELO-BRANCO, Fernando. Lisboa Seiscentista. Lisboa: Livros Horizonte, 1990.

CASTRO, Inês de Ornellas e; BRAGA, Isabel Drumond. Una Escritura Femenina Diferente: los Manuscritos Culinarios Conventuales Portugueses de la Edad Moderna. In: LETURIO, Nieves Baranda; PINA, María Carmen Marín (eds.). Letras en la Celda: cultura Escrita de los Conventos Femeninos de la España Moderna. Madrid: Iberoamericana; Vervuert, 2014, p. 439-455.

CHARTIER, Roger. À beira da falésia. A História entre certezas e inquietudes. Porto Alegre: Ed. UFRGS, 2002.

CONTRERAS, Jesús; GRACIA, Mabel. Alimentação, sociedade e cultura. Rio de Janeiro: Fiocruz, 2011.

DELUMEAU, Jean. 0 pecado e o medo: a culpabilização no ocidente (séculos XIIIXVIII). V. 1. Trad. Álvaro Lorencini. Bauru: Edusc, 2003.

DIAS, Paula Barata. A linguagem dos alimentos nos textos biblicos: sentidos para a fome e para a abundância, Humanitas, v. 60, p. 157-175, 2008.

ELIAS, Norbert. O processo civilizador. Vol. 1: uma história dos costumes. Trad. Ruy Jungmann. Revisão e apresentação: Renato Janine Ribeiro. $2^{a}$ ed. Rio de Janeiro: Zahar, 2011.

FEITLER, Bruno; SOUZA, Evergton Sales (org.). A Igreja no Brasil: normas e práticas durante a Vigência das Constituições Primeiras do Arcebispado da Bahia. São Paulo: Ed. Unifesp, 2011.

FERREIRA, F. A. Gonçalves. História da saúde e dos serviços de saúde em Portugal. Lisboa: Fundação Gulbenkian, 1990.

FIGUEIREDO, Patrick. A “Água de Inglaterra” em Portugal. In: BASTOS, Cristiana; BARRETO, Renilda (Orgs). A circulação do conhecimento: medicina, redes e impérios. Lisboa: Imprensa de Ciências Sociais (UL), 2012, p. 113-130.

FLANDRIN, J. L. A distinção pelo gosto. In: ARIES, P.; CHARTIER, R. História da vida privada: da Renascença ao Século das Luzes. São Paulo: Companhia das Letras, 2009. 
FLANDRIN, Jean-Louis; MONTANARI, Massimo. História da Alimentação. Trad. Luciano Machado e Guilherme Teixeira. São Paulo: Estação Liberdade, 1998.

FLECK, Eliane Cristina Deckmann; DILLMANN, Mauro. "Esta receita é maravilhosa": saberes e práticas curativas na literatura médica publica em Portugal na primeira metade do século XVIII, História (São Paulo), 2021 (no prelo).

FLECK, Eliane Cristina Deckmann; DILLMANN, Mauro. "Para a alma, \& para o corpo he a gula o mais mortal peccado": discursos religiosos e médicos sobre os entendimentos e os efeitos do consumo alimentar exagerado, Portugal, século XVIII. Varia Historia, Belo Horizonte, vol. 37, n. 74, p. 533-564, maio/ago 2021. FLECK, Eliane Cristina Deckmann; DILLMANN, Mauro. "E se o frade quiser ser perfeitinho": instruções para uma conduta exemplar do clero regular português no século XVIII. Revista Maracanan, n. 20, p. 30-50, jan. 2019.

FURTADO, Júnia; RESENDE, Maria Leônia (Orgs.). Travessias inquisitoriais das Minas Gerais aos cárceres do Santo Ofício: diálogos e trânsitos religiosos no império lusobrasileiro (sécs. XVI-XVIII). Belo Horizonte: Fino Traço, 2013.

GANDELMAN, Luciana; GONÇALVES, Mrgareth; FARIA, Patricia Souza de (Orgs.). Religião e Linguagem nos mundos ibéricos: identidades, vínculos sociais e instituições. Seropédica: Ed. UFRRJ, 2015.

GÉLIS, Jacques. O corpo, a Igreja e o sagrado. In: VIGARELLO, Georges (Dir.). História do corpo. V. 1: Da Renascença às Luzes. Trad. Lúcia Orth; revisão Ephraim Alves. $2^{\text {a }}$ ed. Petrópolis: Vozes, 2008, p. 19-130.

HERMANN, Jacqueline; MARTINS, William de Souza (Orgs.). Poderes do Sagrado: Europa católica, América ibérica, África e Oriente portugueses (séculos XVI-XVIII). Rio de Janeiro: Multifoco, 2016.

HUIZINGA, Johan. O outono da Idade Média: estudo sobre as formas de vida e pensamento dos séculos XIV e XV na França e nos Países Baixos. Trad. Francis Janssen. São Paulo: Cosac Naify, 2010.

MACIEL, Maria Eunice; CASTRO, Helisa Canfield de. A comida boa para pensar: sobre práticas, gostos e sistemas alimentares a partir de um olhar socioantropológica, Demetria: Alimentação, nutrição \& saúde, 8 (supl. 1), p. 321-328, 2013.

MARTINS, William de Souza. Modelos de santidade no Período Moderno segundo o Portugal ilustrado pelo sexo feminino (1734). In: FLECK, Eliane Cristina Deckmann; DILLMANN, Mauro (Orgs.). o Universo letrado da Idade Moderna: escritoras e 
escritores portugueses e luso-brasileiros, séculos XVI-XIX. São Leopoldo: Oikos/ Unisinos, 2019.

MONTELEONE, Joana. Sobre reis, livros e cozinheiros: notas para uma pequena história dos tratados de cozinha em português. In: ALGRANTI, Leila Mezan; MEGIANI, Ana Paula (Orgs). O Império por Escrito: formas de transmissão da cultura letrada no mundo ibérico, séculos XVI-XIX. São Paulo: Alameda, 2009, p. 427-438.

NOGUEIRA, André Luís L. “Comida como remédio": agentes de cura e receitas médicas no setecentos. Revista do Arquivo Geral da cidade do Rio de Janeiro, n. 14, p. 19-40, 2018.

PEREIRA, Milena da Silveira. Uma nova bebida para curar em terras lusas (século XVIII). In: FRANÇA, Susani Silveira; VIOTTI, Ana Carolina (Orgs.). Cuidar do espírito e do corpo entre o velho e os novos mundos (séculos XIII-XVIII). São Carlos: Eduscar, 2019, p. 395-408.

QUELLIER, Florent. Gula: história de um pecado capital. Trad. Gian Bruno Grosso. São Paulo: Senac São Paulo, 2011.

RENOUARD, Y. O grande comércio do vinho na Idade Média. Revista de História (USP), v. 6, n. 14, p. 301-314, 1953.

RIPE, Fernando. A constituição do sujeito infantil moderno na cultura impressa portuguesa do século XVIII. Tese de doutorado em Educação, PPGE, Universidade Federal de Pelotas, 2019.

RODRIGUES, Aldair Carlos; et. al. (Orgs.). Edificar e transgredir: clero, religiosidade e Inquisição no espaço ibero-americano (séculos XVI-XIX). Jundiaí: Paco Editorial, 2016.

SÁNCHEZ, Carlos Alberto González. El espíritu de la imagen: arte y religión en el mundo hispánico de la Contrarreforma. Madrid: Cátedra, 2017.

VIOTTI, Ana Carolina. Da mesa à mesinha, a alimentação como remédio (século XVIII). In: ALGRANTI, Leila Mezan; MACÊDO, Sidiana da Consolação (Orgs.). História e Alimentação: Brasil, séculos XVI-XXI. Belém: Paka-Tatu, 2020, p. 46-69.

VON HOFFMANN, Viktoria. From Gluttony to Enlightenment: the world of taste in Early Modern Europe. Urbana: University of Illinois Press, 2016. 